\title{
Particle formation and growth at five rural and urban sites
}

\author{
C.-H. Jeong ${ }^{1}$, G. J. Evans ${ }^{1}$, M. L. McGuire ${ }^{1}$, R. Y.-W. Chang ${ }^{1,4}$, J. P. D. Abbatt ${ }^{1,4}$, K. Zeromskiene ${ }^{2}$, \\ M. Mozurkewich ${ }^{2}$, S.-M. Li ${ }^{3}$, and W. R. Leaitch ${ }^{3}$ \\ ${ }^{1}$ Southern Ontario Centre for Atmospheric Aerosol Research, University of Toronto, 200 College Street, \\ Toronto, Ontario, M5S 3E5, Canada \\ ${ }^{2}$ Chemistry Department and Centre for Atmospheric Chemistry, York University, 4700 Keele Street, \\ Toronto, Ontario, M3J 1P3, Canada \\ ${ }^{3}$ Science and Technology Branch, Environment Canada, 4905 Dufferin Street, Toronto, Ontario, M3H 5T4, Canada \\ ${ }^{4}$ Department of Chemistry, University of Toronto, 80 St. George Street, Toronto, Ontario, M5S 3H6, Canada
}

Received: 12 March 2010 - Published in Atmos. Chem. Phys. Discuss.: 3 May 2010

Revised: 11 August 2010 - Accepted: 12 August 2010 - Published: 27 August 2010

\begin{abstract}
Ultrafine particle (UFP) number and size distributions were simultaneously measured at five urban and rural sites during the summer of 2007 in Ontario, Canada as part of the Border Air Quality and Meteorology Study (BAQS-Met 2007). Particle formation and growth events at these five sites were classified based on their strength and persistence as well as the variation in geometric mean diameter. Regional nucleation and growth events and local short-lived strong nucleation events were frequently observed at the near-border rural sites, upwind of industrial sources. Surprisingly, the particle number concentrations at one of these sites were higher than the concentrations at a downtown site in a major city, despite its high traffic density. Regional nucleation and growth events were favored during intense solar irradiance and in less polluted cooler drier air. The most distinctive regional particle nucleation and growth event during the campaign was observed simultaneously at all five sites, which were up to $350 \mathrm{~km}$ apart. Although the ultrafine particle concentrations and size distributions generally were spatially heterogeneous across the region, a more uniform spatial distribution of UFP across the five areas was observed during this regional nucleation event. Thus, nucleation events can cover large regions, contributing to the burden of UFP in cities and potentially to the associated health impacts on urban populations. Local short-lived nucleation events at the three near-border sites during this summer three-week campaign were associated with high $\mathrm{SO}_{2}$, which likely originated from US and Canadian industrial sources. Hence, particle formation in southwestern Ontario appears to often be related to anthropogenic gaseous emissions but biogenic emissions at
\end{abstract}

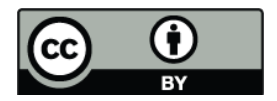

Correspondence to: G. J. Evans (greg.evans@utoronto.ca) times also contribute. Longer-term studies are needed to help resolve the relative contributions of anthropogenic and biogenic emissions to nucleation and growth in this region.

\section{Introduction}

Over the last decade, formation of particles and their subsequent growth in the atmosphere have been found to occur in many different environments (e.g., Alam et al., 2003; Jeong et al., 2004; Dunn et al., 2004; Wehner et al., 2004; Mönkkönen et al., 2005; Mejia et al., 2007; Charron et al., 2007). Measurement of the number and size distributions of ultrafine particles (UFP, $D_{\mathrm{p}}<100 \mathrm{~nm}$ ) has made possible the identification of particle nucleation events, which are found to exhibit large spatial and temporal variability. The concentrations of sulphuric acid and organic compounds, precursors to particle nucleation and growth, are believed to be important factors, and these may vary across locations and meteorological conditions (Kulmala et al., 2005; Boy et al., 2008). However, particle formation events can occur on a large scale. Stanier et al. (2004) found that particle nucleation events occurred at both an urban background site in Pittsburgh, Pennsylvania, USA and an upwind, rural site $38 \mathrm{~km}$ away. Wehner et al. (2007) investigated particle formation events at an urban site in Leipzig and at three rural areas located $\sim 10 \mathrm{~km}$ to $50 \mathrm{~km}$ from this urban background site in Germany; this study revealed that new particle formation events at the four sites took place nearly simultaneously with similar intensities. For evaluation on a larger spatial scale, several studies have investigated simultaneous measurements at rural and remote background sites at distances of $\sim 200 \mathrm{~km}$ to $\sim 1500 \mathrm{~km}$ in Finland, Sweden, and Estonia (Tunved et al.,

Published by Copernicus Publications on behalf of the European Geosciences Union. 
2003; Vana et al., 2004; Dal Maso et al., 2007; Hussein et al., 2009). Hussein et al. (2009) compared the long-term measurements of particle number size distributions at five widely separated urban, rural, and remote background sites (up to $\sim 1500 \mathrm{~km}$ ); in this study particle nucleation events were found to take place over the whole region, although the events rarely occurred. In terms of the vertical evolution of particle formation events, Birmili et al. (2003) investigated particle size distributions in mountainous regions in southern Germany. A uniform spatial distribution of particle formation events was observed at two rural sites separated by $3 \mathrm{~km}$ horizontally and $0.3 \mathrm{~km}$ vertically. On the west coast of Ireland, the horizontal and vertical extent of coastal nucleation events has been found to reach up to $\sim 180 \mathrm{~km}$ and $\sim 1 \mathrm{~km}$, respectively (O'Dowd, 2002).

Knowledge of the formation and evolution of particles is critical to understanding their health and climate effects. Many epidemiological and exposure studies have shown positive associations of respiratory and cardiovascular health effects with exposure to UFP (e.g., Peters et al., 1997; Oberdörster et al., 2002). New particle formation can also be an important source of cloud condensation nuclei and thus influence climate (Seinfeld and Pandis, 2006). However, an understanding of the underlying nucleation and growth processes is still in the formative stages.

Ultrafine particle number and size measurements were simultaneously made at five urban and rural sites located $40 \mathrm{~km}$ to $350 \mathrm{~km}$ apart in southwestern Ontario, Canada, as part of the Border Air Quality and Meteorology Study in the summer of 2007 (BAQS-Met 2007). The border area in this region has Canada's highest $\mathrm{PM}_{2.5}$ mass concentrations (Environment Canada, 2007). The high pollutant concentrations coupled with the unusual meteorology induced by the nearby Great Lakes was an important motivation for this study. In addition, the study offered a unique opportunity to explore ultrafine particle nucleation and growth at rural and urban sites surrounded by numerous local and regional sources of gaseous pollutants and particulate matter (PM). It was also suspected that the meteorology and local topography influence the spatial and temporal distributions of particle number concentrations in this region.

We used simultaneous measurements of UFP number and size distributions at multiple sites to explore the spatial extent of new particle formation and to attempt to identify sources and processes contributing to UFP across the study region. The specific objectives of this study were to distinguish between regional and local nucleation events based on simultaneously measured particle number concentrations at five rural and urban sites influenced by regional and local industrial as well as traffic sources; to evaluate their relationship with meteorological parameters and atmospheric pollutant concentrations; and to determine the degree of inter-site homogeneity in terms of the occurrence of events and consistency in the temporal variability of UFP number concentrations. The overall goals were to improve understanding of

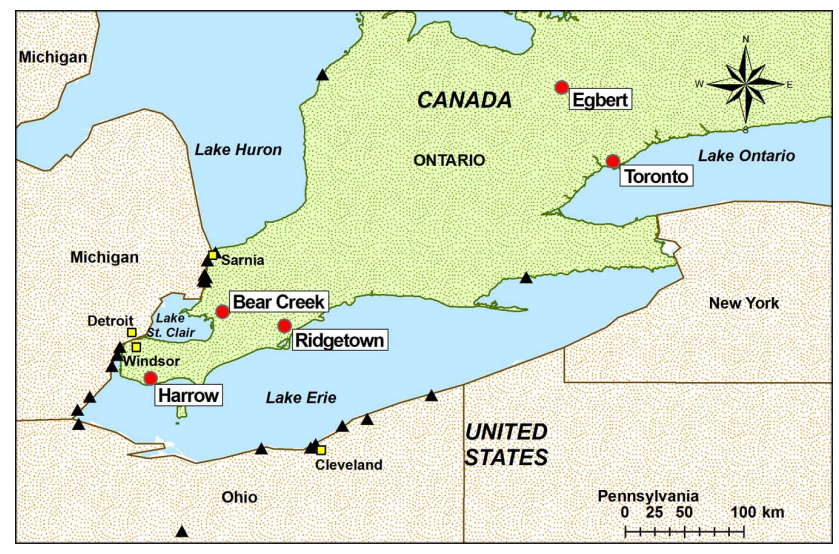

Fig. 1. Locations of the five monitoring sites (dots) and coal-fired power plants (triangles).

the influence of local and regional nucleation events on UFP concentrations in urban and rural areas and provide information needed to resolve the impact of UFP on the health of urban and rural residents.

\section{Experimental methods}

\subsection{Monitoring sites}

The BAQS-Met 2007 intensive field campaign was conducted to investigate the effects of transport and lake breezes on pollutant levels in southwestern Ontario, as well as to determine the sources of these pollutants. Measurement of ambient pollutants and meteorological parameters was simultaneously conducted from 20 June to 8 July 2007 at five sites: Harrow, Bear Creek, Ridgetown, Egbert, and Toronto. As shown in Fig. 1, the monitoring sites at Harrow, Bear Creek, and Ridgetown are geographically located in a border airshed region shared by Canada and the United States, so local air quality was typically impacted by regional and long-range transported pollutants from both Canada and the US. Wind rose plots (Fig. 2) indicated that the wind at the three near-border sites was predominantly from the southwest, the direction of numerous US and Canadian industrial point sources. The Harrow site, for example, located within $5 \mathrm{~km}$ of the shore of Lake Erie in an agricultural area, had dominant southwesterly winds with strong wind speeds; it was influenced by long-range transported pollutants from the US and, more locally, by emissions from the Detroit/Windsor industrial region. The monitoring site at Ridgetown is located $\sim 10 \mathrm{~km}$ from the Lake Erie shoreline. The wind rose analysis at Ridgetown indicated strong southwesterly winds. The Bear Creek monitoring site is located $\sim 70 \mathrm{~km}$ northeast of the Harrow site, close to Lake St. Clair on the eastern shore $(\sim 10 \mathrm{~km})$. Major oil refineries in Sarnia, Ontario and a power plant are located $\sim 50 \mathrm{~km}$ and $\sim 30 \mathrm{~km}$ northwest of 


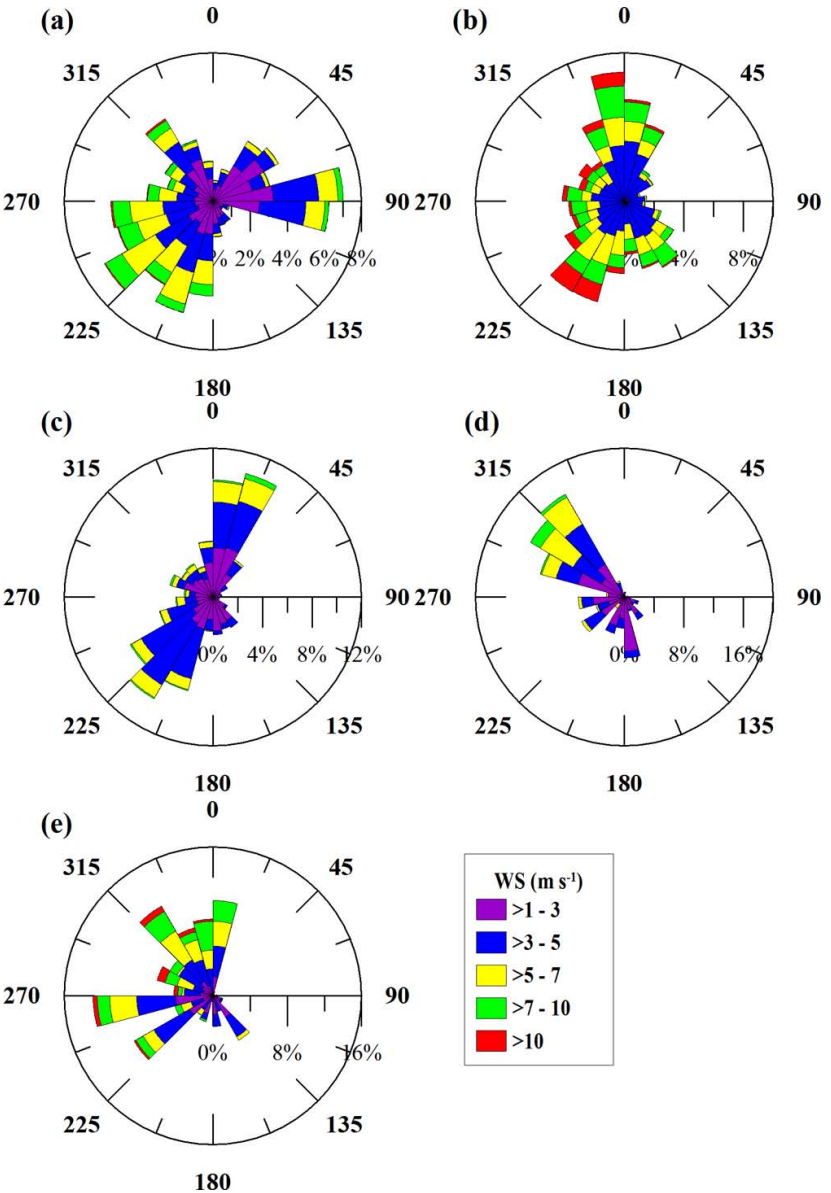

Fig. 2. Wind rose plots for the five monitoring sites with 36 compass directions along with wind speed distribution: Harrow (a), Ridgetown (b), Bear Creek (c), Egbert (d), and Toronto (e).

Bear Creek, so the air quality was impacted by emissions from Detroit/Windsor, industrial regions in Ohio, and the oil refinery facilities. The Egbert data were taken at the Environment Canada Centre for Atmospheric Research Experiments located in rural Egbert, Ontario, $\sim 350 \mathrm{~km}$ northeast of the Harrow site. The Egbert site was mostly influenced by regional-scale sources (Rupakheti et al., 2005). During the campaign, generally clean continental air masses from the northwest reached Egbert, with minimal impact of urban air masses from the south. At the metropolitan site, measurements were made at a laboratory of the Southern Ontario Centre for Atmospheric Aerosol Research (SOCAAR) at the University of Toronto. SOCAAR, which is located in downtown Toronto and surrounded by multi-story buildings, is $20 \mathrm{~m}$ from a busy road. The site was frequently impacted by long-range transported air masses containing industrial pollutants from the US and Canada (Buset et al., 2006).
Table 1. Particle number and size distribution measurement parameters for the five sites during the BAQS-Met campaign.

\begin{tabular}{lllll}
\hline Site & Instruments & CPC & Size Range & $\begin{array}{l}\text { Time } \\
\text { resolution }\end{array}$ \\
\hline Harrow & FMPS & N/A & $6-560 \mathrm{~nm}$ & $1 \mathrm{~s}$ \\
Ridgetown & SMPS & TSI 3010 & $9-640 \mathrm{~nm}$ & $5 \mathrm{~min}$ \\
Bear Creek & SMPS & TSI 3010/ & $10-422 \mathrm{~nm} /$ & $5 \mathrm{~min}$ \\
& & TSI 3775 & $14-673 \mathrm{~nm}$ & \\
Egbert & SMPS & TSI 3025 & $10-440 \mathrm{~nm}$ & $15 \mathrm{~min}$ \\
Toronto & SMPS & TSI 3786 & $3-100 \mathrm{~nm}$ & $2 \mathrm{~min}$ \\
\hline
\end{tabular}

\subsection{Measurements of particle number and size distributions}

The number and size distributions of UFP in the selected size range of $14 \mathrm{~nm}$ to $100 \mathrm{~nm}$ were measured from 20 June to 8 July 2007 by a TSI 3091 Fast Mobility Particle Sizer (FMPS, TSI, St. Paul, MN) at the Harrow site and by four Scanning Mobility Particle Sizers (SMPSs, TSI, St. Paul, $\mathrm{MN}$ ), one at each of the other sites. The FMPS uses 22 electrometers to measure the number and size distributions of particles from $6 \mathrm{~nm}$ to $560 \mathrm{~nm}$ in 32 channels every second. The high time resolution data make it possible to detect rapid changes in particle number and size distributions. However, due to distortions in the particle counting and sizing efficiency of the FMPS, data for particles in the size range of $8 \mathrm{~nm}-100 \mathrm{~nm}$ were corrected as suggested by Jeong and Evans (2009). In addition, size distributions of particles larger than $100 \mathrm{~nm}$ measured by the FMPS were adjusted based on polystyrene latex (PSL) calibration particles and the results of laboratory comparison experiments with the SMPS used for Toronto. After correction, the FMPS and SMPS showed good agreement (Jeong and Evans, 2009). The SMPSs used at the other sites consisted of Differential Mobility Analyzers (DMA) and Condensation Particle Counters (CPC) (Table 1). A TSI 3085 nano-DMA (TSI, St. Paul, MN) was used for the Toronto site, while four TSI 3081 longDMAs (TSI, St. Paul, MN) were used for the other sites. Prepared PSL and $\mathrm{NaCl}$ aerosols were used for calibration and consistency checks of the aerosol instruments. Comparison of particle number concentrations measured by the SMPSs used for the Toronto and Egbert sites showed an excellent correlation $\left(r^{2}=0.99\right)$, although the SMPS used for Toronto tended to report values $\sim 18 \%$ higher than number concentrations from the SMPS for Egbert. The SMPS data were not corrected for this difference. At Bear Creek, particles were counted by a TSI 3010 CPC from 20 June to 25 June and a TSI 3775 CPC from 25 June to 8 July. To reconcile the different detection size ranges and intervals, the particle number and size data for $14 \mathrm{~nm}$ and $100 \mathrm{~nm}$ were used to compare the sites. Continuous measurements of $\mathrm{PM}_{2.5}$ and meteorological parameters were also performed at all sites. $\mathrm{SO}_{2}$ concentrations were also available except for the Ridgetown site. 
Due to their proximity to Lake Erie, Lake St. Clair, and Lake Huron, ambient pollutant concentrations at the three near-border sites can be impacted by meteorology associated with the lakes, such as lake and land breezes (Hastie et al., 1999; Makar et al., 2010). During the BAQS-Met 2007 campaign, Environment Canada conducted analysis of lake breeze events using comprehensive measurements from both land and lake mesonet sites to assess the importance of the chemical and dynamical influences of the Great Lakes on regional air quality (Makar et al., 2010). The effect of lake breezes on particle number concentrations was investigated for Harrow, Ridgetown and Bear Creek.

\subsection{Condensation sink and condensable vapor concentration}

Particle formation rates were represented using the observed nucleation rates $(\mathrm{dN} / \mathrm{dt})$ from $14 \mathrm{~nm}$ to $25 \mathrm{~nm}$, neglecting any coagulation loss. The number concentrations of particles $(14 \mathrm{~nm}-25 \mathrm{~nm})$ at the start and end of a period during which a linear increase was observed were used to quantify the apparent formation rate. Geometric mean diameters (GMD) for each size distribution were used to examine particle growth processes. The observed growth rate (GR) of the newly formed particles was quantified by fitting the GMD of particles smaller than $100 \mathrm{~nm}$ during the particle formation event:

$\mathrm{GR}=\frac{\Delta \mathrm{GMD}}{\Delta t}$

To quantify the condensational growth and sink of newly formed particles, the condensation sink (CS) was estimated based on the analysis by Kulmala et al. $(2001,2005)$ and Dal Maso et al. (2005). In brief, the condensation sink, the rate of loss of molecules onto existing particles, was obtained by integrating over the size distribution as follows

$$
\begin{aligned}
& \mathrm{CS}=2 \pi D \int D_{\mathrm{p}} \beta_{M}\left(D_{\mathrm{p}}\right) n\left(D_{\mathrm{p}}\right) d D_{\mathrm{p}} \\
& =2 \pi D \sum_{i} \beta_{M i} D_{\mathrm{p} i} N_{i}
\end{aligned}
$$

where $D$ is the diffusion coefficient, $\beta_{M}$ is the transitional regime correction factor, $D_{\mathrm{p} i}$ is the particle diameter of size class $i$, and $N_{i}$ is the particle number concentration in size class $i$. The transitional correction factor was expressed as (Fuchs and Sutugin, 1971)

$$
\begin{aligned}
& \beta_{M}=\frac{K n+1}{1.33 \alpha^{-1} K n^{2}+1.33 \alpha^{-1} K n+0.38 K n+1} \\
& =\frac{K n+1}{1.33 K n^{2}+1.71 K n+1}
\end{aligned}
$$

with Knudsen number $K n=2 \lambda / D_{\mathrm{p}}$, where $\lambda$ is the mean free path of the gas molecules under standard conditions $(\sim 67 \mathrm{~nm})$, and the accommodation coefficient $\alpha$ is assumed to be unity.

\subsection{Wind sector and spatial variation analyses}

To ascertain the likely geographic direction of local sources of UFP, a conditional probability function analysis (CPF; Ashbaugh et al., 1985) was conducted based on particle number concentrations in the size range of $14 \mathrm{~nm}-100 \mathrm{~nm}$ (Fig. 4). The CPF provided a metric of the probability that high UFP concentrations were related to specific wind directions, with high values typically associated with local sources. The $\mathrm{CPF}$ was calculated as

$\mathrm{CPF}=\frac{m_{\Delta \theta}}{n_{\Delta \theta}}$

where $m_{\Delta \theta}$ is the number of times the particle number concentration exceeds a certain threshold criterion (the 75th percentile in this study) when the wind arrives from a given wind sector $\left(\Delta \theta, 15^{\circ}\right)$, and $n_{\Delta \theta}$ is the total number of times the wind comes from the same sector. The CPF values containing wind sectors with a low frequency $\left(n_{\Delta \theta}<2\right)$ were divided by three to avoid over-interpretation of CPF values from underrepresented wind sectors.

The spatial distribution of particle number concentrations at the five sites was determined using correlation analysis and coefficients of divergence (COD) for the ten pairs: Harrow-Ridgetown $(95 \mathrm{~km})$; Harrow-Bear Creek (72 km); Harrow-Toronto (340 km); Harrow-Egbert $(350 \mathrm{~km})$; Ridgetown-Bear Creek $(40 \mathrm{~km})$; RidgetownToronto (245 km); Ridgetown-Egbert (260 km); Bear CreekToronto $(270 \mathrm{~km})$; Bear Creek-Egbert $(280 \mathrm{~km})$; and Toronto-Egbert $(80 \mathrm{~km})$. The COD was calculated as

$\mathrm{COD}_{j k}=\sqrt{\frac{1}{p} \sum_{i=1}^{p}\left[\left(N_{i j}-N_{i k}\right) /\left(N_{i j}+N_{i k}\right)\right]^{2}}$

where $N_{i j}$ and $N_{i k}$ represent the hourly $i$-th concentration measured at sampling sites $j$ and $k$, respectively, and $p$ is the number of samples (Wongphatarakul et al., 1998). The COD provided information about the relative inter-site uniformity, with a COD of zero indicating no inter-site variability, and a high COD value (approaching 1) indicating high inter-site variability. In addition to the analysis of spatial uniformity, inter-site associations for different particle size ranges were determined by calculating Spearman rank correlation coefficients $(r)$ for site pairs.

\section{Results and discussion}

\subsection{Comparison of particle number and size distributions}

Number concentrations of $14 \mathrm{~nm}-100 \mathrm{~nm}$ particles across the five sites are presented in Table 2. Thirty-minute average particle concentrations comprising a total of 567 samples for each site were used for this comparison. The highest average 
Table 2. Descriptive statistics for number concentrations $\left(\# \mathrm{~cm}^{-3}\right)$ of particles in the size ranges $14 \mathrm{~nm}$ to $100 \mathrm{~nm}$ and $14 \mathrm{~nm}$ to $25 \mathrm{~nm}$ at the five sites during the BAQS-Met campaign (20 June-8 July 2007).

\begin{tabular}{llrrrrrrrrrr}
\hline $\begin{array}{l}D_{\mathrm{p}} \\
(\mathrm{nm})\end{array}$ & Site & Mean & $\begin{array}{r}\text { Geo. } \\
\text { Mean }\end{array}$ & Median & Std. Dev. & Min & Max & $\begin{array}{r}\text { Lower } \\
\text { Quartile }\end{array}$ & $\begin{array}{r}\text { Upper } \\
\text { Quartile }\end{array}$ & $\begin{array}{r}\text { Percentile } \\
\text { 10th }\end{array}$ & $\begin{array}{r}\text { Percentile } \\
90 \text { th }\end{array}$ \\
\hline & Harrow & 12180 & 9070 & 8750 & 10630 & 1010 & 72340 & 5540 & 15770 & 3510 & 23440 \\
& Ridgetown & 2760 & 1930 & 2070 & 3030 & 70 & 29720 & 1140 & 3100 & 680 & 5420 \\
$14-100$ & Bear Creek & 7560 & 4720 & 4350 & 8910 & 440 & 70440 & 2500 & 9020 & 1320 & 17000 \\
& Egbert & 2870 & 2090 & 2100 & 2520 & 170 & 22070 & 1210 & 3580 & 770 & 6090 \\
& Toronto & 8010 & 6720 & 7290 & 4530 & 780 & 27850 & 4370 & 10630 & 2970 & 14810 \\
\hline & Harrow & 3620 & 810 & 890 & 7690 & 0 & 60920 & 290 & 3060 & 110 & 9420 \\
& Ridgetown & 870 & 300 & 260 & 2070 & 0 & 21000 & 130 & 600 & 60 & 2030 \\
$14-25$ & Bear Creek & 2570 & 740 & 470 & 4620 & 0 & 38840 & 240 & 2430 & 140 & 8530 \\
& Egbert & 550 & 260 & 250 & 1320 & 30 & 12490 & 130 & 470 & 80 & 810 \\
& Toronto & 3160 & 2470 & 2710 & 2200 & 170 & 16240 & 1630 & 4070 & 900 & 6060 \\
\hline
\end{tabular}

was found at Harrow, an agricultural area, while the number concentrations at Ridgetown and Egbert were the lowest. Interestingly, the particle number concentration at the agricultural site was higher than that at the downtown metropolitan site in Toronto, despite its high traffic density. A similar trend was observed when the particle size range was expanded to $8 \mathrm{~nm}-100 \mathrm{~nm}$ : the average particle number concentration was $10500 \pm 6000 \mathrm{~cm}^{-3}$ (average \pm standard deviation) at Toronto, as compared with $16400 \pm 16700 \mathrm{~cm}^{-3}$ at Harrow. However, the median number concentration for the smaller particles $(14 \mathrm{~nm}-25 \mathrm{~nm})$ was highest at Toronto. The 10th percentile concentration for $14 \mathrm{~nm}-25 \mathrm{~nm}$ particles at Toronto was also higher by factors of 6-14 than those for the other sites, indicating higher background concentrations at Toronto due to traffic emissions. As shown in Table 2, there was a factor of $\sim 85$ difference between the $90 \%$ and $10 \%$ percentile concentrations for Harrow as compared with $\sim 7$ for Toronto. Harrow was impacted by intermittent, strong and short-lived nucleation events, causing the UFP concentration to rise sporadically from low to high values. In contrast, Toronto was continuously affected by a baseline of $<25 \mathrm{~nm}$ particles from vehicular exhaust.

Figure 3 presents the average size distributions for UFP at the five sites. While the size distribution in Toronto exhibits a near-single mode at $\sim 30 \mathrm{~nm}$ with a minor peak at the lowest size, a distinct bimodal distribution is observed for Harrow, with modes of $\sim 14 \mathrm{~nm}$ and $\sim 39 \mathrm{~nm}$. The $14 \mathrm{~nm}$ mode was caused by strong particle nucleation events, with persistent subsequent growth of newly formed particles. During the BAQS-Met campaign, several strong peaks in the $\sim 39 \mathrm{~nm}$ size mode were found for Harrow without growth events (e.g., 27 June). This was likely due to the transport of slightly aged particles formed upwind of Harrow. High particle number concentrations corresponded with high wind speeds $\left(\sim 10 \mathrm{~m} \mathrm{~s}^{-1}\right)$, most often originating from the southwest (Figs. 2a and 4a). Hence, major power plants located in

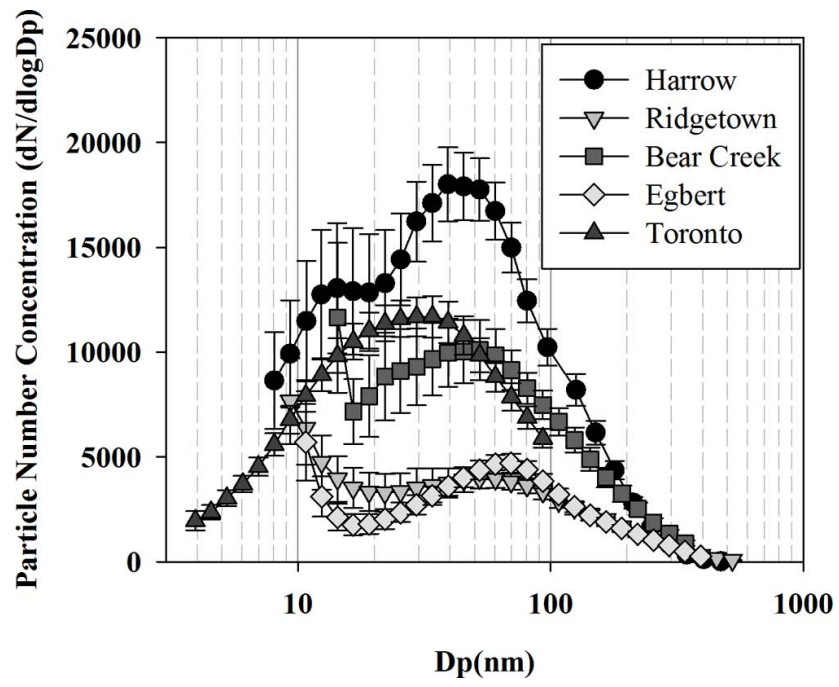

Fig. 3. Average particle size distributions at the five sites. Error bars represent standard errors.

Toledo, Ohio and $\sim 60 \mathrm{~km}$ southwest of the Harrow site were possible sources of these slightly aged $(<\sim 2 \mathrm{~h})$ particles in the Harrow area.

Bimodal distributions were commonly observed at the monitoring sites, except for Toronto. A number of studies conducted in urban areas have observed unimodal particle size distributions of particles larger than $10 \mathrm{~nm}$ (Harrison et al., 1999; Despiau and Croci, 2007; Krudysz et al., 2009). Krudysz et al. (2009) found unimodal size distributions in the $14 \mathrm{~nm}$ to $736 \mathrm{~nm}$ range, with a mode range of $20 \mathrm{~nm}-$ $60 \mathrm{~nm}$, at urban sites in southern California. Harrison et al. (1999) found a distinct unimodal size distribution peaking at $\sim 30 \mathrm{~nm}$ for an urban background $\sim 250 \mathrm{~m}$ from any major road and a more bimodal distribution, with modes of $<10 \mathrm{~nm}$ and $\sim 30 \mathrm{~nm}$, at a site $\sim 2 \mathrm{~m}$ from the curb of a busy 

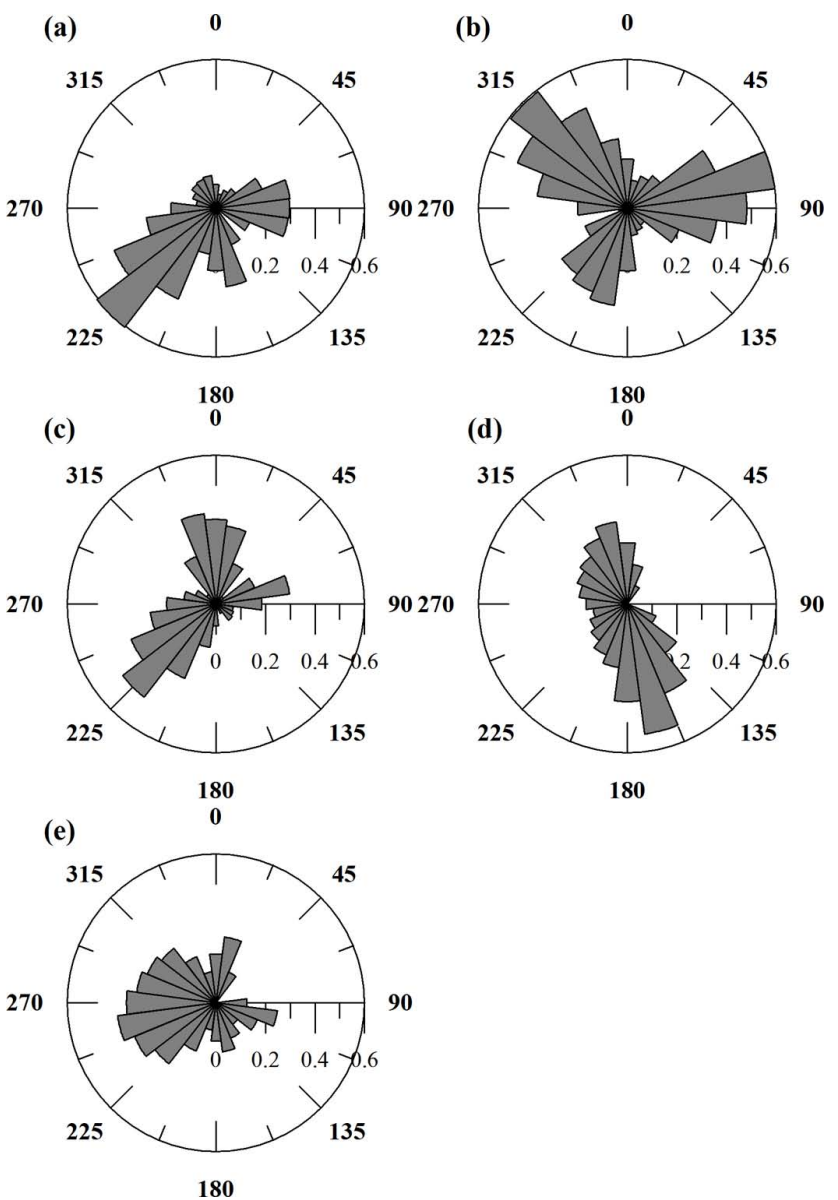

180

As shown in Fig. 3, the particle size distribution at the remote site (Egbert) was close to the average for Ridgetown. Although average concentrations were lower than at other sites, the size distributions observed at Ridgetown and $\mathrm{Eg}$ bert were bimodal, with an accumulation mode of $\sim 60 \mathrm{~nm}$ which likely corresponds to regional aerosol. The accumulation mode is prominent due to less frequent nucleation and longer growth processes, without abrupt changes in meteorological conditions. The mesoscale weather phenomena were different for Ridgetown, where the weather was often cloudy and rainy during the measurement period. These meteorological conditions might explain the lower concentrations at Ridgetown compared to those at Harrow and Bear Creek, despite the close proximity of the three measurement sites. The CPF plot (Fig. 4b) for the particle number concentrations at Ridgetown shows that high particle number concentrations were observed when winds were from the northwest, while the CPF analysis (Fig. 4d) for high particle number concentrations at Egbert showed a stronger contribution from the south, indicating anthropogenic influences from urban areas.

In summary, the size distribution and number concentrations can vary substantially between rural sites and appear to be influenced by the frequency and intensity of nucleation and growth events. Such events can produce number concentrations that exceed those near high traffic.

\subsection{Classification of particle nucleation and growth events}

Size distribution time series at the five sites are depicted in Fig. 5. The color scale represents the number concentration (dN/dlogDp) of particles in each size class. The types of nucleation and growth events at the five sites can be classified by visual inspection of the particle evolution. Atmospheric particle nucleation studies have suggested different types of nucleation events and criteria for characterizing them (e.g., Boy and Kulmala, 2002; Dal Maso et al., 2005; Jeong et al., 2006; Qian et al., 2007). However, the classification of nucleation events is still somewhat subjective as standardized criteria do not exist. In this study, criteria based on temporal changes in the number concentration and geometric mean diameter (GMD) were used to classify events, an approach more objective than one relying alone on visual inspection of the growth curves.

The nucleation and growth events were classified based on their intensity and persistence into Class I, Class II, and Class N. Any continuous increase in the number concentration of particles smaller than $25 \mathrm{~nm}$ for at least $1 \mathrm{~h}$ from 07:00 a.m. to 03:00 p.m. (EDT) was considered to be a particle nucleation event. Class I represents the strongest nucleation and growth events, involving increases in the number concentration of particles smaller than $25 \mathrm{~nm}$ and continuous growth to larger mode particles. An event was designated as Class I if it lasted for at least $3 \mathrm{~h}$, with a gradual increase in the GMD. Events with a high particle formation rate and little 

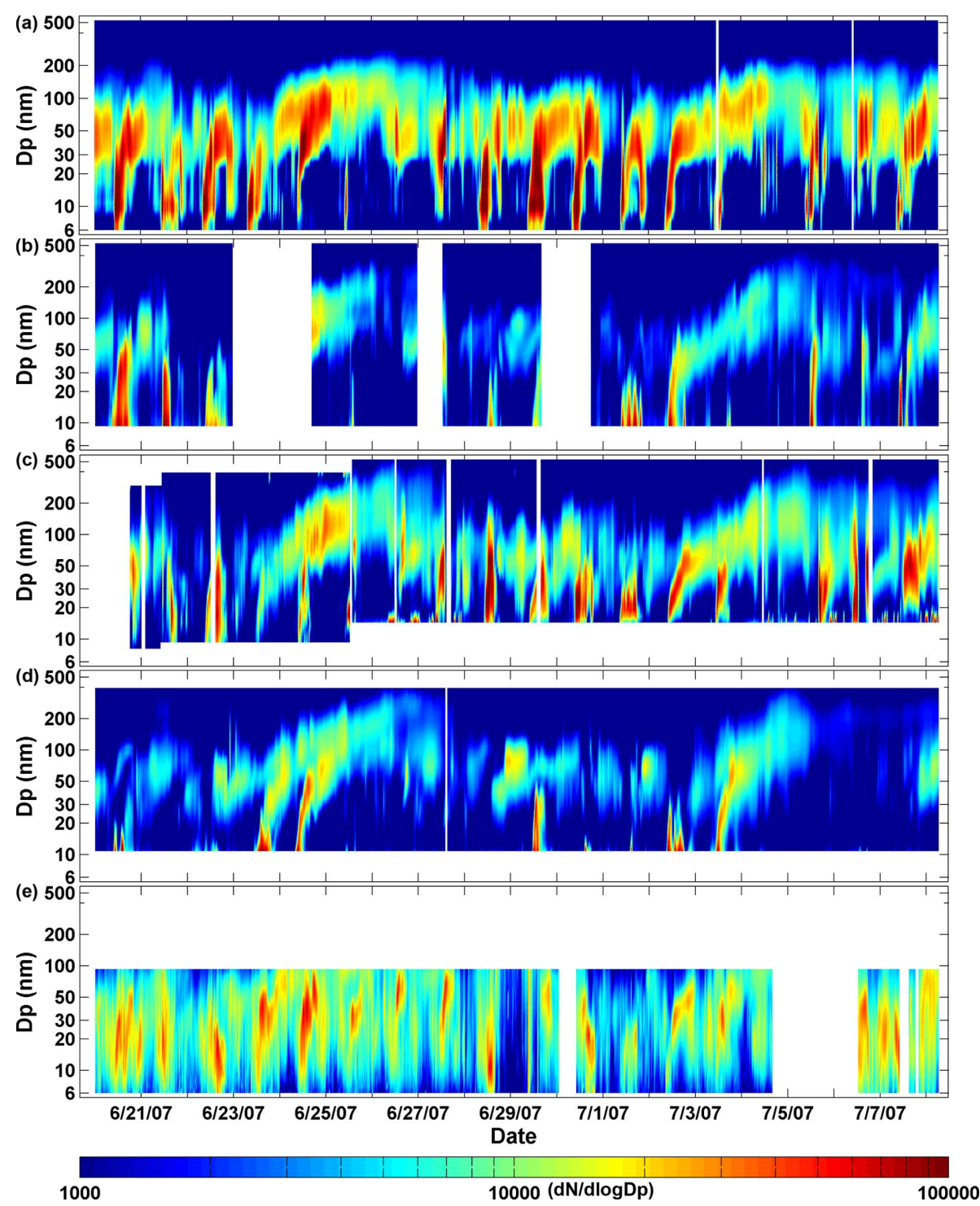

Fig. 5. Evolution of particle number and size distributions at the five sites: Harrow (a), Ridgetown (b), Bear Creek (c), Egbert (d), and Toronto (e).

or no subsequent growth of nucleated particles were classified as Class II. Non-nucleation days comprise Class N.

Figure 6 shows examples of the diurnal variation in the number concentration of particles smaller than $25 \mathrm{~nm}$ and the GMD of particles $<100 \mathrm{~nm}$ during the two types of nucleation events. The difference between the maximum and the minimum concentration during the nucleation period was calculated to determine the apparent formation rate $(\mathrm{dN} / \mathrm{dt})$. The formation rates at Harrow were approximately $11 \mathrm{~cm}^{-3} \mathrm{~s}^{-1}$ and $17 \mathrm{~cm}^{-3} \mathrm{~s}^{-1}$ on 23 June and 25 June, respectively (Fig. 6). A sharp decrease in the GMD was typically observed at the beginning of a Class I event as a result of the formation of new particles, while a gradual increase in the GMD was seen during the subsequent growth of these newly formed particles (Fig. 6a). The elapsed time between the start point (the smallest GMD) and the end point of the period of linear increase in the GMD was used to estimate the growth rate $\left(\mathrm{GR} ; \mathrm{nm} \mathrm{h}^{-1}\right)$ of nucleated particles. The growth event in Fig. 6a was observed for around $8 \mathrm{~h}$, and the corresponding growth rate was $3 \mathrm{~nm} \mathrm{~h}^{-1}$. There was another particle burst during the nucleation event on 23 June at Harrow. This event occurred at around 11:00 a.m., with the change in wind direction from the east $\left(\sim 100^{\circ}\right)$ to the south $\left(\sim 200^{\circ}\right)$. The air parcel from Lake Erie (to the south) showed lower number concentrations of nucleation mode particles and more mature size distributions than those corresponding to the first peak. The abrupt change of wind direction at around 11:00 a.m. was consistent with a lake breeze event observed by Environment Canada. Typically, the wind direction observed at the Harrow site fluctuated, and the particle 


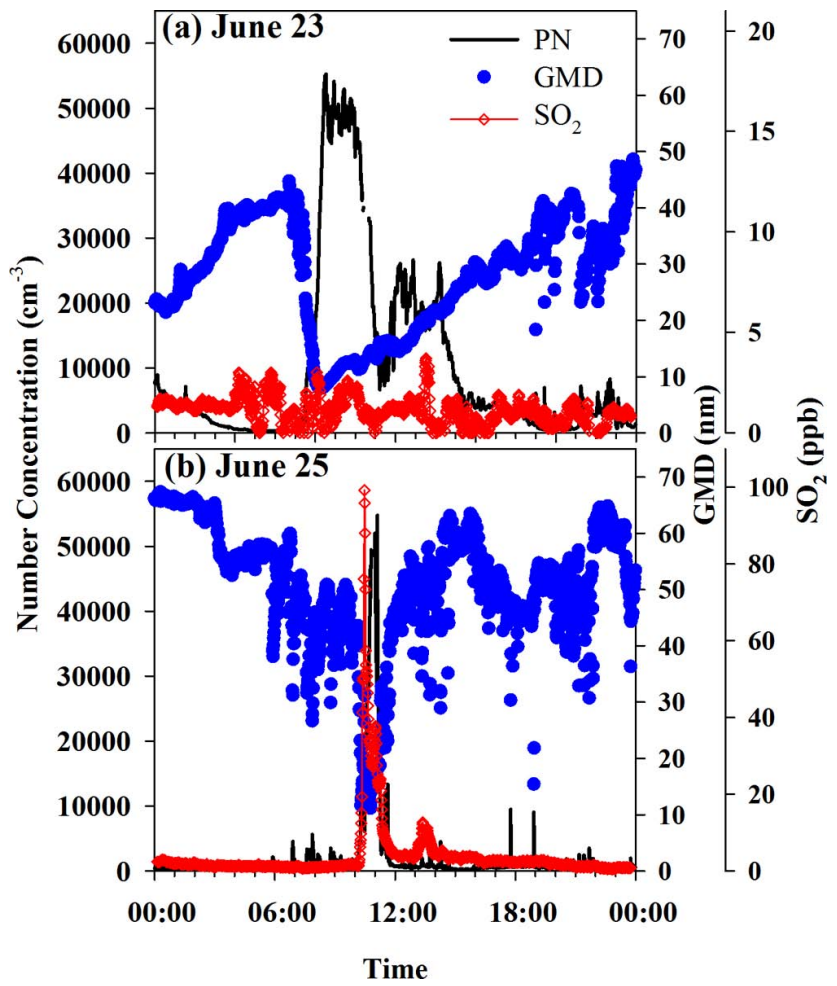

Fig. 6. Examples of the variations in the number concentration of particles (PN, $<25 \mathrm{~nm}$ ) and geometric mean diameter for particles smaller than $100 \mathrm{~nm}$ during particle nucleation and growth events measured at Harrow on 23 June - Class I, (a) and 25 June Class II, (b), respectively.

nucleation and growth events were strongly affected by this meteorological variability. The effect of lake breezes on particle number concentration is discussed in Sect. 3.3.

During the Class II event on 25 June, the number concentration of particles smaller than $25 \mathrm{~nm}$ increased from $1600 \mathrm{~cm}^{-3}$ at 10:10 a.m. to $52000 \mathrm{~cm}^{-3}$ at 11:00 a.m., with an abrupt change in GMD variations. The wind direction changed from the south to the east during this strong particle formation event. This Class II event was likely associated with local-scale particle formation taking place in a plume. The atmospheric parameters responsible for particle nucleation and growth events are discussed in more detail later in this section.

The types of particle nucleation events at the five sites were compiled (Table 3). Nucleation events were more challenging to resolve in Toronto than at the other sites due to the high variability of the number concentrations arising from the high traffic density at this downtown site. Thus, the classification at the Toronto site was based on moving averages of particle number concentrations. In addition to the classification of nucleation events, meteorological parameters and $\mathrm{SO}_{2}$ concentrations between 07:00 a.m. and 03:00 p.m. (EDT) were compiled (Table 3). While there were several days when events were observed at more than one site, there was only one day, 2 July, when Class I events were observed at all five sites; 26 June was the only nonevent day for all five sites. During the period from 20 June to 7 July 2007 the hottest temperature was recorded on 26 June with constant wind from southwesterly directions $\left(205-263^{\circ}\right)$ across the region. These will be referred to hereafter as the "event day" and the "non-event day". Class I nucleation and growth events were most frequently observed at the Harrow site, while no Class II events were observed at Toronto or Egbert. The high frequency of both regional (Class I) and local (Class II) nucleation events in Harrow resulted in the highest average number concentration at this site.

\subsection{Effect of meteorological parameters}

Variations in temperature, relative humidity (RH), wind speed (WS), wind direction (WD), and solar irradiance were compared based on the occurrence of nucleation events at the five sites. The ambient temperature during the Class I event days was, on average, $\sim 5^{\circ} \mathrm{C}$ lower than on non-event days at Harrow. The temperature was also lower on event days by $3-5^{\circ} \mathrm{C}$ at the other four sites. On average, the RH was about $13 \%$ lower on event days (Class I) compared with non-event days (Class N). As shown in Table 3, much higher average $\mathrm{RH}$ was observed at Ridgetown $(70 \pm 11 \%)$ than the average of $58 \pm 9 \%$ observed at Harrow and Bear Creek, the two closest sites. A negative correlation between the occurrence of nucleation events and RH has previously been noted (Boy and Kulmala, 2002; Bonn and Moortgat, 2003; Jeong et al., 2006; Boy et al., 2008). Bonn et al. (2002) proposed that new particles are formed from stabilized Criegee intermediates produced during the ozonolysis of organic molecules. Boy et al. (2008) suggested that the stabilized Criegee intermediates decompose into more volatile products by reacting with water molecules. It is also possible that the growth of pre-existing particles due to the uptake of water vapor may decrease particle formation rates (Charron et al., 2007). The inhibiting effect of water vapor on particle nucleation is a possible explanation for the frequent observation, in this field study, of nucleation and growth events on days with lower $\mathrm{RH}$ and lower ambient temperature. In addition to the higher $\mathrm{RH}$, more frequent rain might partially explain the lower average number concentration of UFP at Ridgetown. The RH at Egbert $(66 \pm 10 \%)$ was also slightly higher than average, possibly contributing to the lower frequency of Class I type nucleation events at this site.

Wind direction also appeared to influence the occurrence of particle nucleation and growth events, whereas no dependence on wind speed was found. The dominant wind direction ( $>50 \%)$ for non-event days was the southwest and south, directions often associated with above-average concentrations of $\mathrm{PM}_{2.5}$. Comparisons were made of the air mass origin at all five sites during the event days (Fig. 7) and the nonevent days (Fig. S1 in the Supplementary Material), based on 
Table 3. Classification of particle formation events and average values of selected parameters between 07:00 a.m. and 03:00 p.m.

\begin{tabular}{|c|c|c|c|c|c|c|c|c|c|c|c|c|c|c|c|c|c|c|c|}
\hline Sites & & $6 / 20$ & $6 / 21$ & $6 / 22$ & $6 / 23$ & $6 / 24$ & $6 / 25$ & $6 / 26$ & $6 / 27$ & $6 / 28$ & $6 / 29$ & $6 / 30$ & $7 / 1$ & $7 / 2$ & $7 / 3$ & $7 / 4$ & $7 / 5$ & $7 / 6$ & $7 / 7$ \\
\hline \multirow{7}{*}{ Harrow } & Class & I & $\mathrm{N}$ & I & I & II & II & $\mathrm{N}$ & $\mathrm{N}$ & II & I & II & I & I & II & $\mathrm{N}$ & II & $\mathrm{N}$ & II \\
\hline & Temp & 23 & 25 & 21 & 19 & 22 & 25 & 28 & 26 & 23 & 20 & 23 & 19 & 18 & 22 & 23 & 27 & 24 & 26 \\
\hline & $\mathrm{RH}$ & 45 & 53 & 47 & 50 & 54 & 67 & 65 & 71 & 59 & 56 & 47 & 51 & 56 & 52 & 71 & 60 & 62 & 48 \\
\hline & WS & 3.9 & 6.2 & 3.3 & 3.5 & 4.8 & 4.0 & 5.5 & 7.4 & 3.0 & 3.9 & 3.0 & 5.1 & 4.2 & 3.7 & 4.9 & 4.6 & 3.7 & 4.1 \\
\hline & WD & 244 & 307 & 131 & 176 & 205 & 201 & 240 & 259 & 79 & 83 & 173 & 80 & 119 & 199 & 271 & 267 & 205 & 272 \\
\hline & Solar & 769 & 517 & 764 & 631 & 681 & 644 & 517 & 509 & 593 & 772 & 762 & 745 & 768 & 562 & 292 & 561 & 620 & 741 \\
\hline & $\mathrm{SO}_{2}$ & 2 & 1 & 3 & 2 & 10 & 11 & 4 & 6 & 7 & 3 & 9 & 1 & 1 & 8 & 4 & 4 & 4 & 3 \\
\hline \multirow{7}{*}{ Ridgetown } & Class & I & II & II & $\mathrm{n} / \mathrm{a}$ & $\mathrm{n} / \mathrm{a}$ & II & $\mathrm{N}$ & $\mathrm{n} / \mathrm{a}$ & II & I & $\mathrm{n} / \mathrm{a}$ & II & I & $\mathrm{N}$ & $\mathrm{N}$ & II & Il & II \\
\hline & Temp & 20 & 24 & 19 & 18 & 23 & 25 & 28 & 27 & 22 & 19 & 21 & 17 & 18 & 21 & 20 & 23 & 23 & 25 \\
\hline & $\mathrm{RH}$ & 64 & 64 & 62 & 59 & 63 & 78 & 76 & 82 & 73 & 68 & 55 & 64 & 67 & 68 & 96 & 89 & 69 & 61 \\
\hline & WS & 7.9 & 10.7 & 7.0 & 4.2 & 6.4 & 4.3 & 6.9 & 10.6 & 6.1 & 3.8 & 4.4 & 8.0 & 5.6 & 5.2 & 5.3 & 4.1 & 4.4 & 5.0 \\
\hline & WD & 315 & 301 & 1 & 161 & 169 & 163 & 205 & 233 & 344 & 19 & 339 & 3 & 95 & 133 & 237 & 292 & 319 & 274 \\
\hline & Solar & 776 & 710 & 760 & 766 & 757 & 653 & 702 & 587 & 601 & 780 & 749 & 704 & 756 & 613 & 200 & 510 & 714 & 728 \\
\hline & $\mathrm{SO}_{2}$ & $\mathrm{n} / \mathrm{a}$ & $\mathrm{n} / \mathrm{a}$ & $\mathrm{n} / \mathrm{a}$ & $\mathrm{n} / \mathrm{a}$ & $\mathrm{n} / \mathrm{a}$ & $\mathrm{n} / \mathrm{a}$ & $\mathrm{n} / \mathrm{a}$ & $\mathrm{n} / \mathrm{a}$ & $\mathrm{n} / \mathrm{a}$ & $\mathrm{n} / \mathrm{a}$ & $\mathrm{n} / \mathrm{a}$ & $\mathrm{n} / \mathrm{a}$ & $\mathrm{n} / \mathrm{a}$ & $\mathrm{n} / \mathrm{a}$ & $\mathrm{n} / \mathrm{a}$ & $\mathrm{n} / \mathrm{a}$ & $\mathrm{n} / \mathrm{a}$ & $\mathrm{n} / \mathrm{a}$ \\
\hline \multirow{7}{*}{ Bear Creek } & Class & $\mathrm{n} / \mathrm{a}$ & II & 1 & I & II & I & $\mathrm{N}$ & $\mathrm{N}$ & I & I & II & II & I & I & $\mathrm{N}$ & Il & 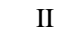 & $\mathrm{N}$ \\
\hline & Temp & 21 & 24 & 19 & 18 & 22 & 25 & 27 & 25 & 21 & 19 & 20 & 17 & 17 & 21 & 20 & 23 & 23 & 24 \\
\hline & RH & 47 & 50 & 51 & 47 & 54 & 67 & 69 & 77 & 62 & 55 & 49 & 55 & 53 & 54 & 81 & 74 & 62 & 55 \\
\hline & WS & 4.8 & 6.4 & 3.6 & 1.6 & 3.3 & 1.9 & 2.7 & 5.4 & 3.4 & 3.1 & 2.7 & 5.4 & 2.9 & 2.5 & 3.4 & 1.9 & 2.6 & 3.1 \\
\hline & WD & 313 & 299 & 13 & 217 & 199 & 223 & 215 & 230 & 7 & 15 & 360 & 10 & 50 & 217 & 226 & 293 & 314 & 242 \\
\hline & Solar & 779 & 735 & 762 & 762 & 763 & 708 & 714 & 472 & 590 & 799 & 706 & 780 & 792 & 644 & 208 & 554 & 691 & 754 \\
\hline & $\mathrm{SO}_{2}$ & 0 & 2 & 4 & 0 & 7 & 8 & 4 & 4 & 11 & 0 & 8 & 1 & 0 & 2 & 2 & 1 & 19 & 2 \\
\hline \multirow{7}{*}{ Egbert } & Class & I & $\mathrm{N}$ & $\mathrm{N}$ & I & 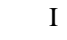 & 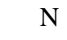 & $\mathrm{N}$ & 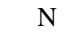 & $\mathrm{N}$ & I & $\mathrm{N}$ & $\mathrm{N}$ & 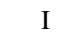 & I & $\mathrm{N}$ & $\mathrm{N}$ & $\mathrm{N}$ & $\mathrm{N}$ \\
\hline & Temp & 16 & 20 & 15 & 15 & 23 & 25 & 28 & 28 & 19 & 18 & 18 & 15 & 17 & 19 & 15 & 22 & 20 & 24 \\
\hline & $\mathrm{RH}$ & 69 & 71 & 65 & 55 & 53 & 60 & 64 & 67 & 71 & 57 & 61 & 66 & 65 & 62 & 96 & 79 & 74 & 56 \\
\hline & WS & 4.8 & 3.8 & 6.0 & 2.7 & 2.3 & 1.8 & 2.8 & 4.1 & 4.8 & 2.3 & 4.0 & 5.1 & 3.2 & 2.6 & 2.5 & 3.2 & 4.5 & 3.9 \\
\hline & WD & 293 & 291 & 312 & 268 & 233 & 232 & 226 & 214 & 311 & 284 & 277 & 316 & 319 & 173 & 136 & 262 & 313 & 247 \\
\hline & Solar & 630 & 659 & 746 & 676 & 696 & 710 & 654 & 583 & 667 & 745 & 733 & 682 & 704 & 570 & 116 & 591 & 700 & 584 \\
\hline & $\mathrm{SO}_{2}$ & 0 & 1 & 0 & 0 & 2 & 3 & 1 & 2 & 0 & 1 & 1 & 0 & 1 & 1 & 1 & 0 & 0 & 0 \\
\hline \multirow{7}{*}{ Toronto } & Class & I & 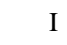 & 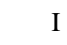 & 2 & 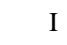 & $\mathrm{N}$ & $\mathrm{N}$ & 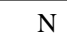 & . & 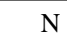 & $\mathrm{n} / \mathrm{a}$ & 1 & - & $\mathrm{N}$ & $\mathrm{N}$ & $\mathrm{n} / \mathrm{a}$ & $\mathrm{n} / \mathrm{a}$ & $\mathrm{n} / \mathrm{a}$ \\
\hline & Temp & 18 & 23 & 18 & 18 & 24 & 26 & 29 & 30 & 24 & 19 & 21 & 17 & 19 & 21 & 18 & 23 & 24 & 25 \\
\hline & RH & 56 & 56 & 50 & 48 & 47 & 52 & 54 & 56 & 52 & 49 & 47 & 53 & 53 & 49 & 87 & 75 & 56 & 47 \\
\hline & WS & 7.9 & 7.3 & 9.3 & 2.9 & 2.9 & 2.5 & 3.8 & 6.5 & 5.3 & 3.1 & 3.5 & 6.1 & 4.4 & 3.3 & 2.7 & 4.2 & 4.6 & 6.0 \\
\hline & WD & 308 & 277 & 332 & 335 & 262 & 257 & 263 & 249 & 324 & 150 & 332 & 350 & 351 & 153 & 157 & 261 & 347 & 260 \\
\hline & Solar & 722 & 724 & 748 & 774 & 757 & 744 & 719 & 594 & 709 & 786 & 641 & 499 & 682 & 669 & 499 & 682 & 669 & 70 \\
\hline & $\mathrm{SO}_{2}$ & 0 & 1 & 0 & 0 & 4 & 5 & 4 & 1 & 0 & 0 & 0 & 0 & 0 & 1 & 1 & 1 & 0 & 0 \\
\hline
\end{tabular}

${ }^{*}$ Temp: ambient temperature $\left({ }^{\circ} \mathrm{C}\right), \mathrm{RH}$ : relative humidity $(\%), \mathrm{WS}$ : wind speed $\left(\mathrm{m} \mathrm{s}^{-1}\right), \mathrm{WD}$ : vector averaged wind direction, Solar: solar irradiance $\left(310-2800 \mathrm{~nm} \mathrm{~W}^{-2}\right), \mathrm{SO}_{2}$ : $\mathrm{ppb}, \mathrm{n} / \mathrm{a}$ denotes missing data.

back trajectories obtained using the National Oceanic and Atmospheric Administration (NOAA) HYbrid Single-Particle Lagrangian Integrated Trajectory (HYSPLIT) model with the Eta Data Assimilation System (EDAS) $40 \mathrm{~km}$ meteorological data (Draxler and Rolph, 2003). Back trajectories were calculated for $24 \mathrm{~h}$ and $48 \mathrm{~h}$, starting between 11:00 a.m. and 12:00 p.m. (EDT), at a height of $100 \mathrm{~m}$ a.g.l (above ground level). Most air masses for the Class I events (Fig. 7a), originated from northern Canada and contained less polluted, cooler, drier air. This is consistent with the finding of Nillson et al. (2001), who observed that nucleation events occurred in arctic and polar air masses that corresponded with cold air advection. Plausible sources for Class I are discussed in Sect. 3.5. In contrast, during the non-event days, the air masses usually came from the south and passed over industrial regions (Fig. S1). Generally, hotter, more humid air masses were associated with higher concentrations of $\mathrm{PM}_{2.5}$.
Nucleation events could be inhibited by high $\mathrm{PM}_{2.5}$ mass concentrations due to the scavenging of condensable vapors by pre-existing particles (Kerminen et al., 2001). The back trajectory analysis (Fig. 7b) for Class II at the near-border sites showed that the air masses passed over industrial areas in Sarnia, Detroit/Windsor, and Ohio, suggesting contributions from anthropogenic emissions.

The variability of particle number concentrations was also influenced by the lake breeze effect discussed earlier. Frequent lake breezes at Harrow, Ridgetown, and Bear Creek were identified using observations from surface mesonets operated by Environment Canada (Table 4). Most of the events were associated with elevated particle number concentrations in the size range of $14 \mathrm{~nm}-100 \mathrm{~nm}$. For example, on 6 July, particle number concentrations during lake breezes increased by a factor of 7 around noon at Harrow, by a factor of 16 around 02:00 p.m. at Ridgetown, and by a factor of 31 around 

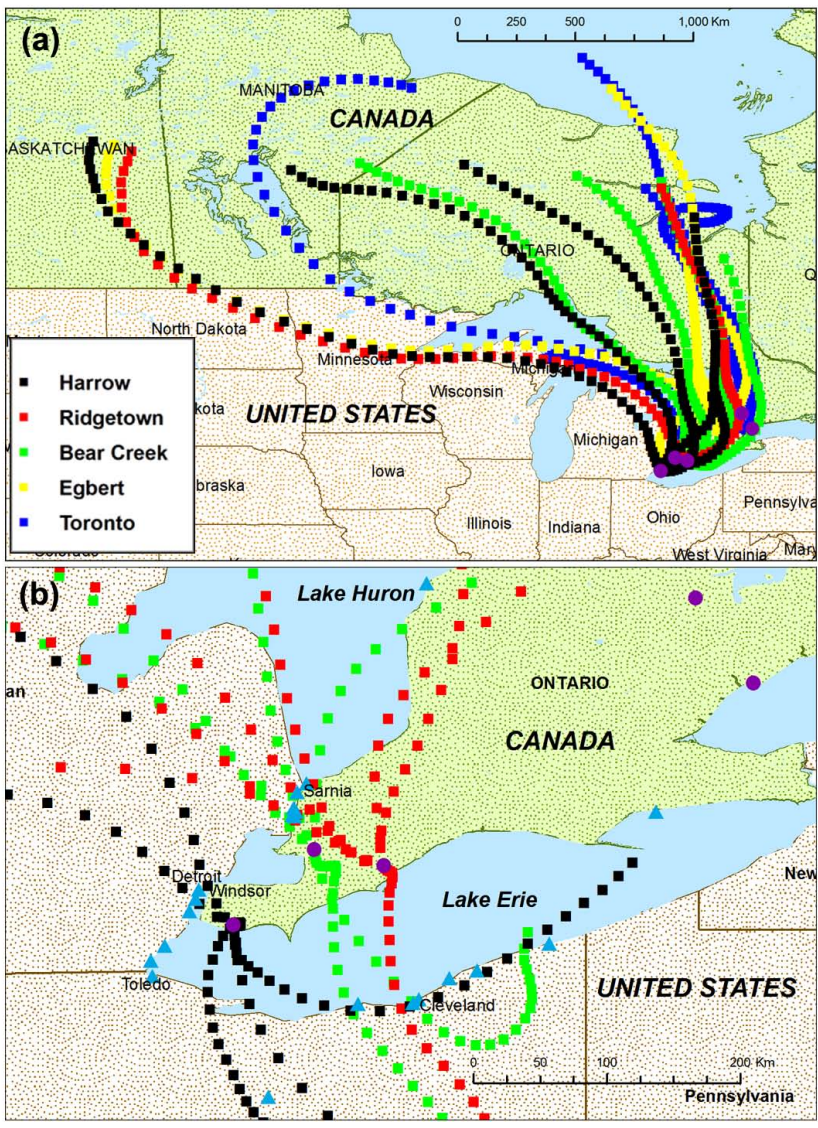

Fig. 7. 48-h back trajectories of all Class I events (a) at the five sites and 24-h back trajectories of 18 Class II events (b) at the nearborder sites. Dots and triangles represent the locations of the five monitoring sites and coal-fired power plants, respectively. Back trajectory data from 28 June to 30 June were not available.

05:00 p.m. at Bear Creek, as compared to 30-min average particle concentrations prior to the lake breezes. During the events, GMDs for the UFP size distributions at the three sites ranged from $38 \mathrm{~nm}$ to $45 \mathrm{~nm}$, indicating that somewhat aged air masses were impacting the sites.

On average, solar irradiance which exhibited a mean of $730 \pm 56 \mathrm{~W} \mathrm{~m}^{-2}$ during Class I event days was $9 \%$ and $33 \%$ stronger than during Class II days and non-event days, respectively. It appears that Class I nucleation events corresponded closely to solar radiation intensity, which is suggestive of the formation of hydroxyl radicals through photochemical processes. During Class I event days, new particle formation began when solar irradiation was as low as $140 \mathrm{~W} \mathrm{~m}^{-2}$ (e.g., 23 June at Harrow). The highest initial value for solar irradiation before a Class I event was $860 \mathrm{~W} \mathrm{~m}^{-2}$ on 29 June at Ridgetown. Alam et al. (2003) reported an analysis of nucleation events at a suburban site in Birmingham, UK, in which particle formation events were also strongly associated with higher levels of solar irradiance ranged from $170 \mathrm{~W} \mathrm{~m}^{-2}$ to $750 \mathrm{~W} \mathrm{~m}^{-2}$.
Table 4. The ratio $\left(R_{\mathrm{L}}\right)$ of 30-min average particle number concentrations during lake breezes to averages prior to the events.

\begin{tabular}{lcccl}
\hline & $\begin{array}{c}\text { Number of } \\
\text { observations }\end{array}$ & $\begin{array}{c}{ }^{\text {a Percentage }} \\
\left(R_{\mathrm{L}}>1.1\right)\end{array}$ & $\begin{array}{c}{ }^{b} \text { Percentage } \\
\left(R_{\mathrm{L}}<0.9\right)\end{array}$ & $\begin{array}{l}\text { Mean } \pm \text { StDev } \\
(\text { Median }) R_{\mathrm{L}}\end{array}$ \\
\hline Harrow & 25 & 54 & 33 & $1.6 \pm 1.4(1.1)$ \\
Ridgetown & 16 & 67 & 11 & $3.2 \pm 5.0(1.4)$ \\
Bear Creek & 21 & 57 & 29 & $5.9 \pm 14.0(1.2)$ \\
\hline
\end{tabular}

a Observation percentage above the increase by a factor of 1.1 .

b Observation percentage below the decrease by a factor of 0.9 .

\subsection{Effect of plume emissions}

Overall average $\mathrm{SO}_{2}$ concentrations at Harrow and Bear Creek were $4.6 \pm 3.2 \mathrm{ppb}$ and $4.2 \pm 4.9 \mathrm{ppb}$, respectively, whereas substantially lower $\mathrm{SO}_{2}$ averages were observed at Toronto $(1.0 \pm 1.6 \mathrm{ppb})$ and Egbert $(0.6 \pm 0.9 \mathrm{ppb})$. High $\mathrm{SO}_{2}$ was associated with the more frequent occurrence of Class II events at the Harrow and Bear Creek sites. The average $\mathrm{SO}_{2}$ concentrations for Class II events were $7.4 \pm 3.0 \mathrm{ppb}$ at Harrow and $7.1 \pm 6.1 \mathrm{ppb}$ at Bear Creek, whereas the $\mathrm{SO}_{2}$ averages for Class I were $2.0 \pm 0.9 \mathrm{ppb}$ and $1.2 \pm 1.8 \mathrm{ppb}$, respectively.

As shown in Fig. 6b, a sharp increase in particle number concentrations (5700 to $12400 \mathrm{~cm}^{-3}$ ) was seen around 10:00 a.m. on 25 June 2007 at Harrow when the wind direction changed from west-south-west $\left(260^{\circ}\right)$ to southeast $\left(135^{\circ}\right)$; the highest $\mathrm{SO}_{2}$ concentration $(\sim 99 \mathrm{ppb})$ also occurred at that time. Substantially increased particle number concentrations were also observed at Bear Creek (2900 to $16800 \mathrm{~cm}^{-3}$ ) and Ridgetown (1300 to $2800 \mathrm{~cm}^{-3}$ ) at noon and 01:00 p.m., respectively, with a high concentration of $\mathrm{SO}_{2}(\sim 14 \mathrm{ppb})$ at Bear Creek. Abrupt changes in wind direction $\left(300^{\circ}\right.$ to $\left.150^{\circ}\right)$ and wind speed $\left(0.5\right.$ to $\left.5.3 \mathrm{~m} \mathrm{~s}^{-1}\right)$ were observed at Ridgetown due to the lake breeze effect, whereas a slight change in wind direction $\left(250^{\circ}\right.$ to $\left.220^{\circ}\right)$ with a stronger wind speed ( 1.6 to $2.9 \mathrm{~m} \mathrm{~s}^{-1}$ ) was observed at Bear Creek during the event. The back trajectory analysis for the 25 June Class II event showed that all trajectories arriving at the Harrow, Bear Creek, and Ridgetown sites originated from the Ohio River Valley, while air masses at Harrow also passed over the northern Ohio industrial region near Lake Erie (Fig. 8b), indicating the impact of fossil fuel combustion. During all Class II event days CPF plots for particle number concentrations in the $14 \mathrm{~nm}$ to $25 \mathrm{~nm}$ size range at the near-border sites were depicted in Fig. S2 (see Supplementary Material). Strong contributions from the southwest and the northwest were observed for Harrow, consistent with the directions of US and Canadian industrial sources. The CPF plots for Ridgetown and Bear Creek point to the north and the northwest sectors indicating oil refinery facilities and a power plant near Sarnia. Hence, these and the other Class II particle formation events were likely caused by sulphuric 

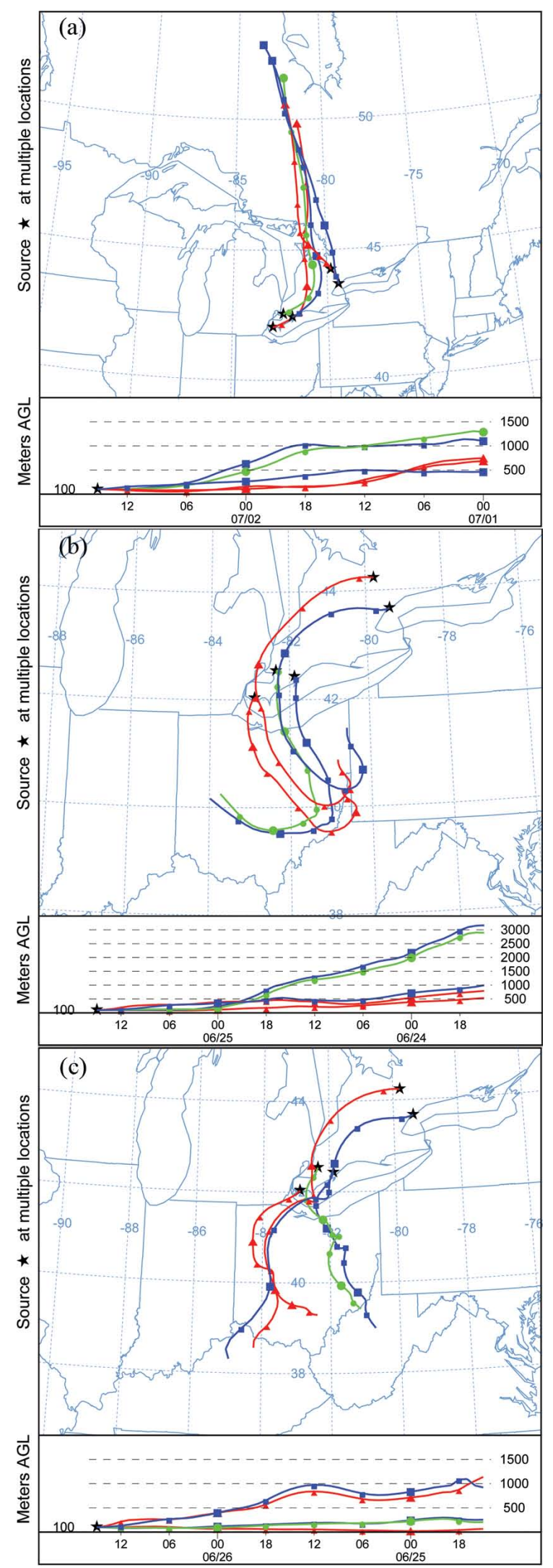

Fig. 8. 48-h back trajectories at the five monitoring sites on 2 July - Class I, (a), 25 June - Class II, (b), and 26 June - non-event, (c). acid nucleation resulting from oxidation of $\mathrm{SO}_{2}$ in a plume. Anthropogenic emissions of $\mathrm{SO}_{2}$ contributed to the occurrence of nucleation events in southwestern Ontario. A high concentration of $\mathrm{SO}_{2}$ in a plume could increase the available condensable vapor concentrations without increasing the condensation sink. Sulphuric acid is a key species associated with nucleation events (Berndt et al., 2005) and events have previously been associated with high $\mathrm{SO}_{2}$ concentration plumes, in studies conducted near stationary sources (e.g., Dunn et al., 2004; Stanier et al., 2004).

No new particle formation was observed on 25 June at the Egbert and Toronto sites. In these regions, the concentration of $\mathrm{SO}_{2}$ also increased when the wind came from the southwest on 25 June, although concentrations were much lower than those at Harrow and Bear Creek. A substantial increase in the concentration of $>60 \mathrm{~nm}$ particles was observed at noon on 25 June at the Toronto site, along with the highest $\mathrm{SO}_{2}$ concentration ( $8 \mathrm{ppb}$ ) during the measurement period. At Egbert, an increase in $\mathrm{SO}_{2}(7 \mathrm{ppb})$ was also observed around 11:00 a.m. without a significant change in nucleation mode particle number concentrations. The HYSPLIT results indicated that air masses at both sites originated from the Ohio industrial region (Fig. 8b). However, the plume emissions originating from the Ohio River Valley were advected into the Toronto and Egbert areas after approximately three days of atmospheric transport. The growth and dilution of particles during transport may explain the $\mathrm{SO}_{2}$ peaks with the presence of larger particles $(>60 \mathrm{~nm})$ observed on 25 June at Egbert and Toronto.

\subsection{Analysis of a regional nucleation event}

Particle formation events (Class I) were observed on 2 July at all five sites, up to $\sim 350 \mathrm{~km}$ apart, indicating a regionalscale nucleation event (Table 3 ). In the urban area, interference from local sources such as motor vehicle exhaust was lower since 2 July was a holiday, which likely made it easier to detect the event at that location. On 23 and 24 June, a weekend, nucleation and growth events were also observed at all sites except Ridgetown (missing data). The particle burst that occurred on 2 July was the most distinctive nucleation and growth event observed during the measurement period. Particle nucleation started between 07:00 a.m. and 10:00 a.m., occurring first at Ridgetown and Egbert. During the nucleation event, the wind was consistently from the north (Toronto and Egbert) and the east (Harrow, Ridgetown, and Bear Creek). The back trajectories in Fig. 8a show that these latter air masses also originated from northern Ontario, indicating that these sites were impacted by clean cool air. Wind speeds at the Egbert site were between $3.6 \mathrm{~m} \mathrm{~s}^{-1}$ and $4.2 \mathrm{~m} \mathrm{~s}^{-1}$ during the nucleation burst, whereas very calm winds $\left(1.1 \mathrm{~m} \mathrm{~s}^{-1}\right)$ were observed before the nucleation event ( $\sim 07: 00$ a.m.). Initiation of the nucleation event was likely related to the arrival at Egbert of this clean air, containing few pre-existing particles. Due to the northerly winds, the 
Table 5. Characteristics of nucleation events observed at the five sites on 2 July 2007.

\begin{tabular}{lcccc}
\hline & $\begin{array}{c}\text { Formation } \\
\text { rate } \\
\left(\mathrm{cm}^{-3} \mathrm{~s}^{-1}\right)\end{array}$ & $\begin{array}{c}{ }^{\mathrm{a}} \mathrm{GR} \\
\left(\mathrm{nm} \mathrm{hr}^{-1}\right)\end{array}$ & $\begin{array}{c}{ }^{\mathrm{a}} \mathrm{CS}_{i} \\
\left(10^{-3} \mathrm{~s}^{-1}\right)\end{array}$ & $\begin{array}{c}{ }^{\mathrm{a}} \mathrm{CS}_{\text {aveg }} \\
\left(10^{-3} \mathrm{~s}^{-1}\right)\end{array}$ \\
\hline Harrow & 4.4 & 6.4 & $0.96 \pm 0.06$ & $3.22 \pm 1.66$ \\
Ridgetown & 3.3 & 4.7 & $0.53 \pm 0.02$ & $1.14 \pm 0.69$ \\
Bear Creek & 3.6 & 2.9 & $0.67 \pm 0.01$ & $2.59 \pm 1.56$ \\
Egbert & 4.7 & 5.1 & $0.83 \pm 0.03$ & $0.71 \pm 0.53$ \\
Toronto & 1.1 & 6.7 & $1.22 \pm 0.26$ & $1.86 \pm 0.96$ \\
\hline
\end{tabular}

a GR: growth rate, $\mathrm{CS}_{i}$ : 1-h average condensation sink prior to the nucleation event, $\mathrm{CS}_{\text {aveg }}$ : 24-h average condensation sink.

ambient temperature on the event day was colder than on other days, with moderate relative humidity. The colder temperature on the nucleation event days following the influence of cool air masses is in agreement with observations in many different locations in Finland, USA, and UK (Nilsson et al., 2001; Stainer et al., 2004; Charron et al., 2007). Hussein et al. (2009) reported that regional-scale new particle formation events at five Nordic background sites were favored in similar air masses from the northern Atlantic Ocean. Most of these air masses are considered clean and not strongly influenced by anthropogenic activity except ship emissions.

In regards to $\mathrm{SO}_{2}$ concentrations, nucleation events at all sites exhibited among the lowest concentrations $(\leq 1 \mathrm{ppb})$, suggesting that on 2 July, the region was less influenced by anthropogenic emissions. Charron et al. (2007) observed that on large-scale nucleation event days $\mathrm{SO}_{2}$ concentrations were generally below $1 \mathrm{ppb}$ with air masses from the northern Atlantic Ocean. While even this low $\mathrm{SO}_{2}$ concentration may be sufficient to produce the $\sim 10^{6}$ molecules $\mathrm{cm}^{-3}$ of $\mathrm{H}_{2} \mathrm{SO}_{4}(\mathrm{~g})$ needed to initiate nucleation, it was likely too low to have supported the observed growth rates presented in Table 5 (Sipilä et al., 2010). Thus, biogenic sources, i.e., terrestrial biota, wetlands and biomass burning, are believed to have played a role in new particle formation and growth at the rural sites, with sulphur contributing to nucleation and organic compounds contributing growth. Biogenic emissions are typically influenced by many factors, including ambient temperature. Slowik et al. (2010) found that biogenic secondary organic aerosol (SOA) mass concentrations steadily increased from a very low concentration $\left(<\sim 1 \mu \mathrm{g} \mathrm{m}^{-3}\right)$ to $\sim 17 \mu \mathrm{g} \mathrm{m}^{-3}$ as ambient temperature gradually increased from $\sim 20^{\circ} \mathrm{C}$ to $\sim 30^{\circ} \mathrm{C}$ (daily maximum) during the period 9-13 June 2007 in Egbert. However, a strong nucleation event was only observed on the first day (9 June) of the biogenic SOA event when organic mass and temperature were lower than other event days. This suggests that the colder temperature would have inhibited biogenic volatile organic compound emissions, limiting the rapid formation of SOA and subsequent scavenging of sulphuric acid. Further emissions of biogenic sulphur compounds may not have the same temperature dependence. Hence the colder temperature on 2 July, could have promoted nucleation by allowing the production and limiting the scavenging of sulphuric acid. Longer-term studies are needed to help resolve the relative contributions of anthropogenic and biogenic emissions to nucleation and growth in this region. This information is needed to help understand the possible influences of newly formed particles on regional climate. The conditions associated with the regional nucleation event on 2 July were characterized in terms of the particle formation rate, the growth rate, and the condensation sink (CS) (Table 5). As shown in Fig. 9c, the condensation sink varied over the duration of the event. In this study, two values for the condensation sink were estimated for each of the five sites: the 1-h average prior to the nucleation event $\left(\mathrm{CS}_{i}\right)$, and the 24-h average $\left(\mathrm{CS}_{\mathrm{aveg}}\right)$. The highest formation rates for particles smaller than $25 \mathrm{~nm}$ were observed at Egbert and Harrow, while the lowest rate was observed at the urban site (Toronto). A high $\mathrm{CS}_{i}$ at the Toronto site might be responsible for its low formation rate: a high condensation sink will scavenge potential condensable vapors responsible for particle nucleation and growth. As expected, the $\mathrm{CS}_{i}$ values at the five sites on the morning of the event day were lower by a factor of 1.1-2.9 than those on the non-event day, 26 June. The occurrence of the highest formation rate with the lowest $\mathrm{CS}_{\text {aveg }}$ at Egbert indicates the presence of rapid particle formation events without effective particle growth. Even though the lowest $\mathrm{CS}_{i}$ was observed at Ridgetown preceding the nucleation event, the new particle formation rate was the second lowest of the five sites. An episode of rain was recorded (01:00 a.m.-07:00 a.m.) before the nucleation event at Ridgetown, during which ambient particles and gaseous species associated with precursors of condensable vapors may have been scavenged, resulting in the depletion of condensable vapors along with the low initial condensation sink. Growth rates (GR) at the five sites ranged from $2.9 \mathrm{~nm} \mathrm{~h}^{-1}$ to $6.7 \mathrm{~nm} \mathrm{~h}^{-1}$. The highest growth rate was observed at the downtown Toronto site. These values are comparable to those found at urban and rural sites in Germany (Wehner et al., 2007), as well as an urban (Alam et al., 2003), and a rural site in the UK (Charron et al., 2007). Wehner et al. (2007) found slightly higher GR ranging from $4.2 \mathrm{~nm} \mathrm{~h}^{-1}$ to $5.5 \mathrm{~nm} \mathrm{~h}^{-1}$ at an urban site than those identified at rural sites. At a rural site in the UK, the measured GR varied between $2 \mathrm{~nm} \mathrm{~h}^{-1}$ and $6 \mathrm{~nm} \mathrm{~h}^{-1}$, while the GR ranged from $3.6 \mathrm{~nm} \mathrm{~h}^{-1}$ to $9.0 \mathrm{~nm} \mathrm{~h}^{-1}$ in the urban area. Kulmala et al. (2005) reported that the GR is higher in polluted areas than in clean environments and suggested a more significant contribution of sulphuric acid to particle growth in urban areas. However, the GR is often many times higher than the rate of the growth due to sulphuric acid alone; for example, most of the nucleated particles in a polluted area of Mexico City were composed of organics and nitrate (Kuang et al., 2008; Smith et al., 2008). Given the similar levels of $\mathrm{SO}_{2}$ and solar intensities on 2 July at all sites, and that Toronto had 


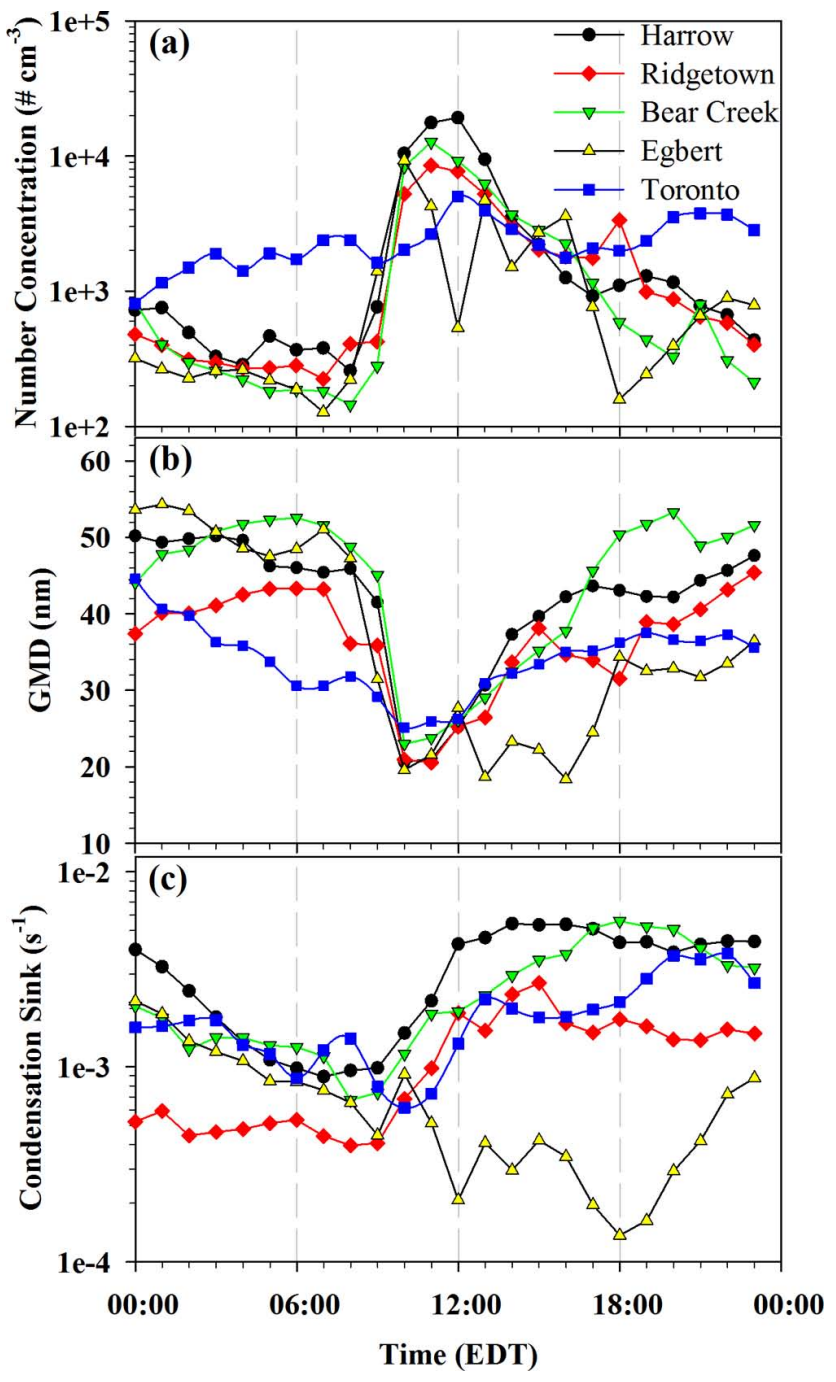

Fig. 9. Number concentrations of particles in the size range of $14 \mathrm{~nm}-25 \mathrm{~nm}$ (a), geometric mean diameters of nucleated particles in the size range of $14 \mathrm{~nm}-100 \mathrm{~nm}$ (b), and condensation sink (c) during the regional nucleation event observed on 2 July 2007.

the highest growth rate yet lowest nucleation rate on this day, it is likely that other components, such as less volatile condensable organics from local sources, contributed to growth at this urban site.

\subsection{Temporal and spatial variability of UFP}

Coefficients of divergence (COD) as a function of particle size were calculated for each site pair based on hourly average measurements over the 18 measurement days (Fig. 10a). On average, COD values were greater than 0.4 for all sizes, with a mean of 0.42 , suggesting a moderate degree of spatial heterogeneity over this large region. There was an inverse linear relationship between COD and particle size, indicating that spatial heterogeneity increased as particle size

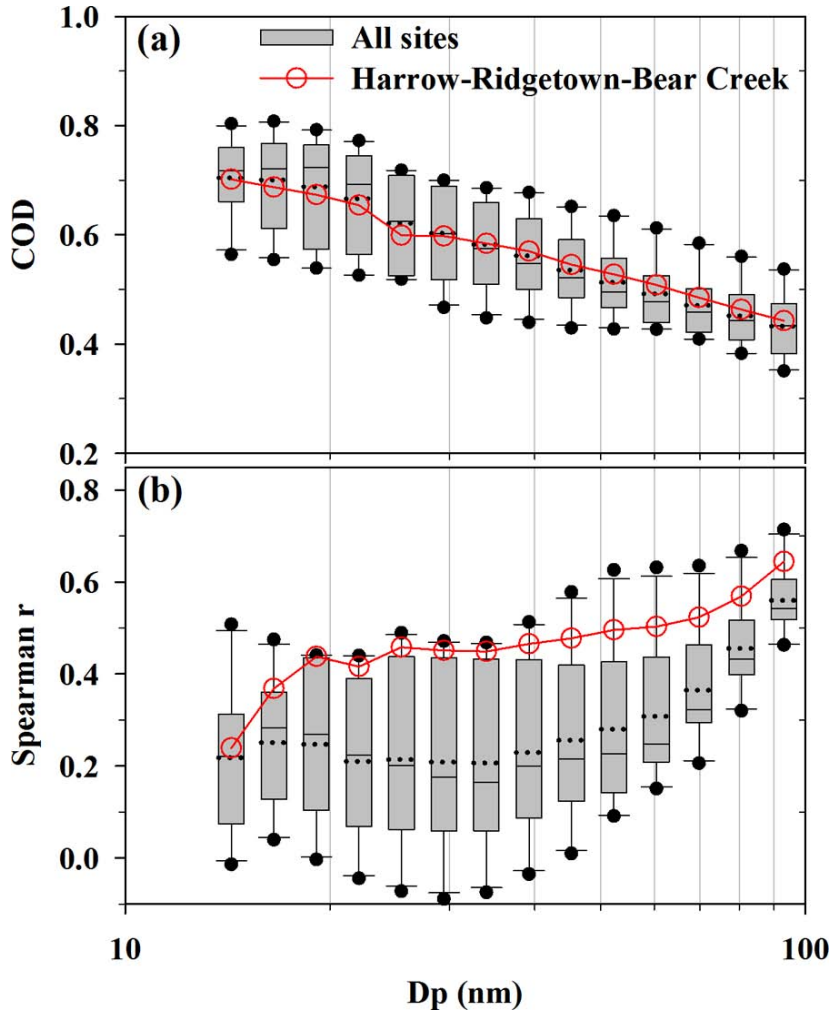

Fig. 10. Variation of CODs (a) and Spearman correlation coefficients (b) as a function of particle size for the five (Harrow, Ridgetown, Bear Creek, Egbert, and Toronto) and three (Harrow, Ridgetown, and Bear Creek) sites during the measurement period. Box-whisker plots demonstrate the median (line), quartile (box), mean (dots), $90 \%$ percentile (whiskers), and $95 \%$ percentile (dots).

decreased. The inverse relationship was consistent with the spatial variability reported at California sites within 0.4$11 \mathrm{~km}$ of each other (Krudysz et al., 2009), although the California study showed less heterogeneity than what was observed in the present study; this is likely due to the smaller spatial scales involved. With respect to the correlation analysis, increased correlation coefficients for particles larger than $40 \mathrm{~nm}$ were observed, while the highest correlation coefficient of 0.71 was observed between Bear Creek and Ridgetown for $93 \mathrm{~nm}$ particles. The correlation between $\mathrm{Eg}$ bert and Toronto, $\sim 80 \mathrm{~km}$ south of the Egbert site, was generally very poor $(r<0.1)$, except for larger particles $(>80 \mathrm{~nm})$, for which the $r$ value was 0.52 . This high temporal variability was presumably driven by the differences in source types between the rural and urban sites and the prevailing meteorological conditions during the campaign. A larger multi-year comparison of nucleation at these two sites is now underway. Notably, particles smaller than $25 \mathrm{~nm}$ showed low $r$ values with high COD values. The differences in the strength and frequency of nucleation events and primary emissions from local sources, as well as the size-dependent fate of UFP in 


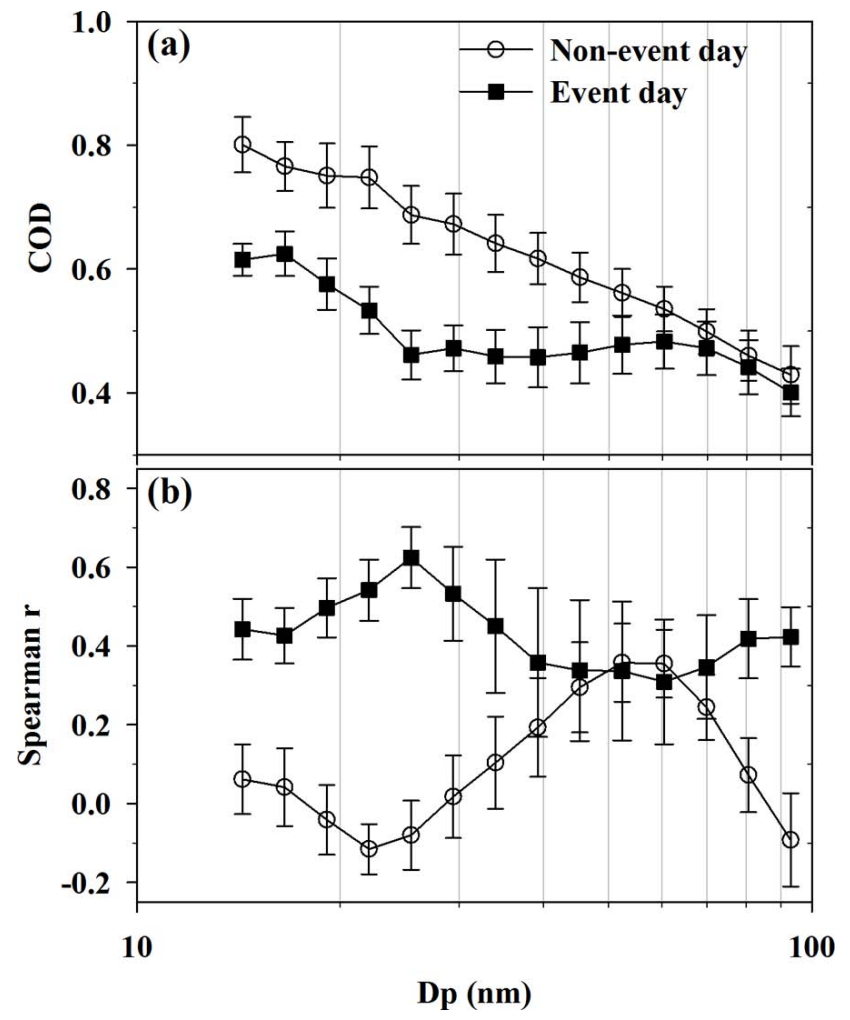

Fig. 11. Average variation of CODs (a) and Spearman correlation coefficients (b) for the five sites during the non-event day (26 June) and the nucleation event day (2 July).

the atmosphere, would result in high spatial divergence for small particles.

To constrain the influence of particle nucleation events on spatial variations, the COD and $r$ values were calculated on the nucleation event day (2 July) and non-event day (26 June) (Fig. 11). The COD values for particles in the $14 \mathrm{~nm}-100 \mathrm{~nm}$ size range during the nucleation event and non-event days were 0.41 and 0.55 , respectively, while the corresponding correlation coefficients were 0.43 (event, $p<0.05$ ) and 0.14 (non-event), indicating more uniform spatial distribution of UFP across the five areas during the regional nucleation event. Interestingly, enhanced spatial homogeneity was observed for smaller particles $(<80 \mathrm{~nm})$, with a greater improvement for particle sizes between $20 \mathrm{~nm}$ and $30 \mathrm{~nm}$, relative to COD values during the non-event day. While the mean COD for the event day at all sites was 0.46 for $25 \mathrm{~nm}$ particles, much lower individual COD values $(0.27-0.38)$ were found for Harrow, Ridgetown, and Bear Creek. In addition, the highest correlation coefficient for $25 \mathrm{~nm}$ particles (a mean $r$ of 0.62) was observed during the event day, with a higher correlation $(r=0.9)$ among Harrow, Ridgetown, and Bear Creek. Thus, although the concentrations and size distributions of ultrafine particles usually were spatially heterogeneous, regional nucleation and growth events could greatly increase the spatial homogeneity and inter-site correlation of these particles.

\section{Conclusions}

Number concentrations and size distributions of particles in the size range of $14 \mathrm{~nm}-100 \mathrm{~nm}$ were simultaneously measured at five rural and urban sites in Southern Ontario during the BAQS-Met campaign. On average, the number concentrations of particles were higher at a near-border agricultural site, Harrow, than the concentration at the downtown Toronto site. This was likely due to the influence of intermittent nucleation events, which caused the UFP concentration to rise from low to high values. However, the highest median number concentrations of particles in the smaller size range $14 \mathrm{~nm}-25 \mathrm{~nm}$ were observed at Toronto, most likely due to persistent production of particles $<25 \mathrm{~nm}$ in motor vehicle exhaust. While the mean size distribution for Toronto exhibited a unimode at $\sim 30 \mathrm{~nm}$, mean bimodal distributions in rural areas were caused by nearby nucleation and growth of smaller particles and transport of larger particles from upwind sources. Wind sector and back trajectory analyses suggested that strong peaks in particle number concentrations at Harrow were often associated with anthropogenic emissions.

Observed nucleation and growth events at these five sites were classified in terms of the strength and persistence of number concentration of particles smaller than $25 \mathrm{~nm}$ and geometric mean diameter variations during the events. The most distinctive type of nucleation and growth event, Class I, was frequently observed at the Harrow site. Strong and short-lived Class II events occurred more often at Harrow, Ridgetown, and Bear Creek than at the downtown Toronto site. The frequent occurrence of regional and local-scale nucleation events at Harrow resulted in the highest of the average number concentrations for these five locations. During Class I nucleation events, the mean temperature and $\mathrm{RH}$ were $19 \pm 2{ }^{\circ} \mathrm{C}$ and $55 \pm 7 \%$, respectively. On Class I event days, the solar radiation flux was approximately $33 \%$ higher than on non-event days. Back trajectory analyses suggested that Class I nucleation and growth events were associated with less polluted cooler drier air from northern Ontario, whereas the air masses during non-event days passed over distant industrial regions to the south (e.g., Ohio River Valley). Class II events at the near-border sites were associated with high $\mathrm{SO}_{2}$, which likely originated from nearby industrialized regions. A nucleation and growth event on 2 July was detected at all five sites, indicating that the event had a spatial extent of at least $350 \mathrm{~km}$. This event was associated with unpolluted air from northern Ontario having relatively low $\mathrm{SO}_{2}$ concentrations and a low condensation sink. The unpolluted air associated with this event suggested that biogenic sources contributed to the growth and possibly the nucleation.

The spatial homogeneity of particle number and size distributions measured simultaneously at the five sites within 
$40-350 \mathrm{~km}$ of each other was assessed by calculating Spearman correlation coefficients and coefficients of divergence. Coefficients of divergence among the five sites were greater than 0.4 for all particle sizes, with higher COD for smaller particles $(<25 \mathrm{~nm})$, indicating that spatial heterogeneity increased as particle size decreased. The inter-site temporal correlations were very weak for smaller particles $(<25 \mathrm{~nm})$, but they increased slightly for larger particles. However, during a regional nucleation event on 2 July, homogeneity was much higher, especially for the closer Harrow, Ridgetown, and Bear Creek sites: for $20 \mathrm{~nm}-30 \mathrm{~nm}$ particles, the lowest COD values were found along with the highest correlation coefficients.

In summary, regional nucleation events were observed even in Toronto, a major urban centre. Thus, particles from regional nucleation processes can contribute to the burden of ultrafine particles in cities, and potentially to the associated health impacts on urban populations. Nonetheless, the high number concentrations at rural sites suggest that care be taken, for now, in the use of particle number as a metric of population exposure. Further research is required to establish the differences in toxicity of particles from nucleation events and those from vehicle emissions. Many short-lived strong particle formation events observed during this summer threeweek campaign were associated with local industrial sources including trans-border air flows from the south and southwest, and with elevated $\mathrm{SO}_{2}$. A regional nucleation event associated with unpolluted air suggested that biogenic emissions may also contribute to particle formation and growth at the three near-border sites in southwestern Ontario. Hence, particle formation and growth in southwestern Ontario are in general related to anthropogenic emissions as well as biogenic emissions. Studies of longer duration will help to resolve the relative contributions of anthropogenic and biogenic emissions to nucleation and growth in this region.

\section{Supplementary material related to this article is available online at: http://www.atmos-chem-phys.net/10/7979/2010/ acp-10-7979-2010-supplement.pdf.}

Acknowledgements. These field measurements were supported by the Ontario Ministry of the Environment and Environment Canada. The subsequent data analysis was supported by the Canadian Foundation for Climate and Atmospheric Science. Funding for SOCAAR was provided by the Canada Foundation for Innovation, the Ontario Innovation Trust, and the Ontario Research Fund. The authors are grateful to David Sills and Ormanda Niebergall of Environment Canada for providing solar irradiance data during the BAQS-Met 2007 campaign and to Jeff Brook of Environment Canada for helpful discussions.

Edited by: J. W. Bottenheim

\section{References}

Alam, A., Shi, J. P., and Harrison, R. M.: Observations of new particle formation in urban air, J. Geophys. Res., 108(D3), 4093, doi:10.1029/2001JD001417, 2003.

Ashbaugh, L. L., Malm, W. W., and Sadeh, W. Z.: A residence time probability analysis of sulfur concentrations at Grand Canyon National Park, Atmos. Environ., 19, 1263-1270, 1985.

Berndt, T., Böge, O., Stratmann, F., Heintzenberg, J., and Kulmala, M.: Rapid formation of sulfuric acid particles at nearatmospheric conditions, Science, 307, 698-700, 2005.

Birmili, W., Berresheim, H., Plass-Dülmer, C., Elste, T., Gilge, S., Wiedensohler, A., and Uhrner, U.: The Hohenpeissenberg aerosol formation experiment (HAFEX): a longterm study including size-resolved aerosol, $\mathrm{H}_{2} \mathrm{SO}_{4}, \mathrm{OH}$, and monoterpenes measurements, Atmos. Chem. Phys., 3, 361-376, doi:10.5194/acp-3-361-2003, 2003.

Biswas, S., Ntziachristos, L., Moore, K. F., and Sioutas, L.: Particle volatility in the vicinity of a freeway with heavy-duty diesel traffic, Atmos. Environ., 41, 3479-3493, 2007.

Bonn, B. and Moortgat, G. K.: Sesquiterpene ozonolysis: Origin of atmospheric new particle formation, Geophys. Res. Lett., 30, 1585, doi:10.1029/GL0017000, 2003.

Bonn, B., Schuster, G., and Moortgat, G. K.: Influence of water vapor on the process of new particle formation during monoterpenes ozonolysis, J. Phys. Chem. A, 106, 2869-2881, 2002.

Boy, M., Karl, T., Turnipseed, A., Mauldin, R. L., Kosciuch, E., Greenberg, J., Rathbone, J., Smith, J., Held, A., Barsanti, K., Wehner, B., Bauer, S., Wiedensohler, A., Bonn, B., Kulmala, M., and Guenther, A.: New particle formation in the Front Range of the Colorado Rocky Mountains, Atmos. Chem. Phys., 8, 15771590, doi:10.5194/acp-8-1577-2008, 2008.

Boy, M. and Kulmala, M.: Nucleation events in the continental boundary layer: Influence of physical and meteorological parameters, Atmos. Chem. Phys., 2, 1-16, doi:10.5194/acp-2-1-2002, 2002.

Buset, K. C., Evans, G. J., Leaitch, W. R., Brook, J. R., and ToomSauntry, D.: Use of advanced receptor modelling for analysis of an intensive 5-week aerosol sampling campaign, Atmos. Environ., 40(Suppl 2), 482-499, 2006.

Charron, A., Birmili, W., and Harrison, R. M.: Factors influencing new particle formation at the rural site, Harwell, UK, J. Geophys. Res., 112, D14210, doi:10.1029/2007JD008425, 2007.

Dal Maso, M., Kulmala, M., Riipinen, I., Wagner, R., Hussein, T., Alto, P. P., and Lehtinen, K. E. J.: Formation and growth of fresh atmospheric aerosols: eight years of aerosol size distribution data from SMEAR II, Hyytiälä, Finland, Boreal Environ. Res., 10, 323-336, 2005.

Dal Maso, M., Sogacheva, L., Aalto, P., Riipinen, I., Komppula, M., Tunved, P., Korhonen, L., Suuruski, V., Hirsikko, A., Kurten, T., Kerminen, V., Lihavainen, H., Viisanen, Y., Hansson, H., and Kulmala, M.: Aerosol size distribution measurements at four Nordic field stations: identification, analysis and trajectories analysis of new particle formation bursts, Tellus B., 59, 350-361, 2007.

Despiau, S. and Croci, D.: Concentrations and size distributions of fine aerosol particles measured at roof level in urban zone, J. Geophys. Res., 112, D09212, doi:10.1029/2006JD007228, 2007. 
Draxler, R. R. and Rolph, G. D.: HYSPLIT (Hybrid SingleParticle Lagrangian Integrated Trajectory) Model access via NOAA ARL READY, http://ready.arl.noaa.gov/HYSPLIT.php, last access: 14 August 2010, NOAA Air Resources Laboratory, Silver Spring, MD, 2003.

Dunn, M. J., Jimenez, J. L., Baumgardner, D., Castro, T., McMurry, P. H., and Smith, J. N.: Measurements of Mexico City nanoparticle size distributions: observations of new particle formation and growth, Geophys. Res. Lett., 31, L10102, doi:10.1029/2004GL019483, 2004.

Environment Canada: http://www.ec.gc.ca/air/default.asp?lang= En\&n=D6F2B21E-1, last access: 14 August 2010, 2007.

Fuchs, N. A. and Sutugin, A. G.: Highly dispersed aerosol, in: International reviews in aerosol physics and chemistry: Topics in current aerosol research, edited by: Hidy, G. M. and Brock, J. R., New York, Pergamon, 1971.

Hastie, D. R., Narayan, J., Schiller, C., Niki, H., Shepson, P. B., Sills, D. M. L., Taylor, P. A., Moroz, W. J., Drummond, J. W., Reid, N., Taylor, R., Roussel, P. B., and Melo, O. T.: Observational evidence for the impact of lake breeze circulation on ozone concentrations in southern Ontario, Atmos. Environ., 33, 323-335, 1999.

Harrison, R. M., Jones, M., and Collins, G.: Measurements of the physical properties of particles in the urban atmosphere, Atmos. Environ., 33, 309-321, 1999.

Hussein, T., Junninen, H., Tunved, P., Kristensson, A., Dal Maso, M., Riipinen, I., Aalto, P. P., Hansson, H.-C., Swietlicki, E., and Kulmala, M.: Time span and spatial scale of regional new particle formation events over Finland and Southern Sweden, Atmos. Chem. Phys., 9, 4699-4716, doi:10.5194/acp-9-4699-2009, 2009.

Jeong, C.-H. and Evans, G. J.: Inter-comparison of a fast mobility particle sizer and a scanning mobility particle sizer incorporating an ultrafine water-based condensation particle counter, Aerosol Sci. Tech., 43, 364-373, 2009.

Jeong, C.-H., Evans, G. J., Hopke, P. K., Chalupa, D., and Utell, M.: Influence of atmospheric dispersion and new particle formation events on ambient particle number concentration in Rochester, USA and Toronto, Canada, J. Air Waste Manage., 56, 431-443, 2006.

Jeong, C.-H., Hopke, P. K., Chalupa, D., and Utell, M.: Characteristics of nucleation and growth events of ultrafine particles measured in Rochester, NY, Environ. Sci. Technol., 38, 1933-1940, 2004.

Kerminen, V.-M., Pirjola, L., and Kulmala, M.: How significantly does coagulational scavenging limit atmospheric particle production?, J. Geophys. Res., 106, 24119-24126, 2001.

Krudysz, M., Moore, K., Geller, M., Sioutas, C., and Froines, J.: Intra-community spatial variability of particulate matter size distributions in Southern California/Los Angeles, Atmos. Chem. Phys., 9, 1061-1075, doi:10.5194/acp-9-1061-2009, 2009.

Kuang, C., McMurry, P. H., McCormick, A. V., and Eisele, F. L.: Dependence of nucleation rates on sulfuric acid vapor concentration in diverse atmospheric locations, J. Geophys. Res., 113, D10209, doi:10.1029/2007JD009253, 2008.

Kulmala, M., Dal Maso, M., Mäkelä, J. M., Pirjola, L., Väkevä, M., Aalto, P., Miikkulainen, P., Hämeri, K., and O'Dowd, C. D.: On the formation, growth and composition of nucleation mode particles, Tellus B, 53, 479-490, 2001.
Kulmala, M., Vehkamäki, H., Petäjä, T., Dal Maso, M., Lauri, A., Kerminen, V.-M., Birmili, W., and McMurry, P. H.: Formation and growth rates of ultrafine atmospheric particles: a review of observation, J. Aerosol Sci., 35, 143-176, 2004.

Kulmala, M., Petäjä, T., Mönkkönen, P., Koponen, I. K., Dal Maso, M., Aalto, P. P., Lehtinen, K. E. J., and Kerminen, V.-M.: On the growth of nucleation mode particles: source rates of condensable vapor in polluted and clean environments, Atmos. Chem. Phys. 5, 409-416, doi:10.5194/acp-5-409-2005, 2005.

Makar, P. A., Zhang, J., Gong, W., Stroud, C., Sills, D., Hayden, K. L., Brook, J., Levy, I., Mihele, C., Moran, M. D., Tarasick, D. W., and He, H.: Mass tracking for chemical analysis: the causes of ozone formation in southern Ontario during BAQSMet 2007, Atmos. Chem. Phys. Discuss., 10, 14241-14312, doi:10.5194/acpd-10-14241-2010, 2010.

Mejia, J. F., Wraith, D., Mengersen, K., and Morawska, L.: Trends in size classified particle number concentration in subtropical Brisbane, Australia, based on a 5 year study, Atmos. Environ., 41, 1064-1079, 2007

Mönkkönen, P., Koponen, I. K., Lehtinen, K. E. J., Hämeri, K., Uma, R., and Kulmala, M.: Measurements in a highly polluted Asian mega city: observations of aerosol number size distribution, modal parameters and nucleation events, Atmos. Chem. Phys., 5, 57-66, doi:10.5194/acp-5-57-2005, 2005.

Nilsson, E. D., Paatero, J., and Boy, M.: Effects of air masses and synoptic weather on aerosol formation in the continental boundary layer, Tellus B, 53, 462-478, 2001.

Oberdörster, G., Sharp, Z., Atudorei, V., Elder, A., Gelein, R., Lunts, A., Kreyling, W., and Cox, C.: Extrapulmonary translocation of ultrafine carbon particles following whole-body inhalation exposure of rats, J. Toxicol. Env. Heal. A, 65, 1531-1543, 2002.

O'Dowd, C.: On the spatial extent and evolution of coastal aerosol plumes, J. Geophys. Res., 107(D19), 8105, doi:10.1029/2001JD000422, 2002.

Peters, A., Wichmann, H. E., Tuch, T., Heinrich, J., and Heyder, J.: Respiratory effects are associated with the number of ultrafine particles, Am. J. Resp. Crit. Care, 155, 1376-1383, 1997.

Qian, S., Sakurai, H., and McMurry, P. H.: Characteristics of regional nucleation events in urban East St. Louis, Atmos. Environ., 41, 4119-4127, 2007.

Rupakheti, M., Leaitch, W. R., Lohmann, U., Hayden, K., Brickell, P., Lu, G., Li, S.-M., Toom-Sauntry, D., Bottenheim, J. W., Brook, J. R., Vet, V., Jayne, J. T., and Worsnop, D. R.: An intensive study of the size and composition of submicron atmospheric aerosols at a rural site in Ontario, Canada, Aerosol Sci. Tech., 39, 722-736, 2005.

Seinfeld, J. H. and Pandis, S. N.: Atmospheric chemistry and physics: From air pollution to climate change, John Wiley, New York, 2006.

Sipilä, M., Berndt, T., Petäjä, T., Brus, D., Vanhanen, J., Stratmann, F., Patokoski, J., Mauldin III, R. L., Hyvärinen, A.-P., Lihavainen, H., and Kulmala, M.: The role of sulfuric acid in atmospheric nucleation, Science, 327, 1243-1246, 2010.

Slowik, J. G., Stroud, C., Bottenheim, J. W., Brickell, P. C., Chang, R. Y.-W., Liggio, J., Makar, P. A., Martin, R. V., Moran, M. D., Shantz, N. C., Sjostedt, S. J., van Donkelaar, A., Vlasenko, A., Wiebe, H. A., Xia, A. G., Zhang, J., Leaitch, W. R., and Abbatt, J. P. D.: Characterization of a large biogenic secondary 
organic aerosol event from eastern Canadian forests, Atmos. Chem. Phys., 10, 2825-2845, doi:10.5194/acp-10-2825-2010, 2010.

Smith, J. N., Dunn, M. J., VanReken, T. M., Iida, K., Stolzenburg, M. R., McMurry, P. H., and Huey, L. G.: Chemical composition of atmospheric nanoparticles formed from nucleation in Tecamac, Mexico: Evidence for an important role for organic species in nanoparticle growth, Geophys. Res. Lett., 35, L04808, doi:10.1029/2007GL032523, 2008.

Stanier, C. O., Khlystov, A. Y., and Pandis, S. N.: Nucleation events during the Pittsburgh air quality study: Description and relation to key meteorological, gas phase and aerosol parameters, Aerosol Sci. Tech., 38, 253-264, 2004.

Tunved, P., Nilsson, E. D., Hansson, H.-C., and Ström, J.: Aerosol characteristics of air masses in northern Europe: Influences of location, transport, sinks, and sources, J. Geophys. Res., 110, D07201, doi:10.1029/2004JD005085, 2005.

Vana, M., Kulmala, M., Dal Maso, M., Hörrak, U., and Tamm, E.: Comparative study of nucleation mode aerosol particles and intermediate air ions formation events at three sites, J. Geophys. Res., 109, D17201, doi:10.1029/2003JD004413, 2004.

Wehner, W., Birmili, W., Gnauk, T., and Wiedensohler, A.: Particle number size distributions in a street canyon and their transformation into the urban-air background: measurements and a simple model study, Atmos. Environ., 36, 2215-2223, 2002.
Wehner, B., Wiedensohler, A., Tuch, T. M., Wu, Z. J., Hu, M., Slanina, J., and Kiang, C. S.: Variability of the aerosol number size distribution in Beijing, China: new particle formation, dust storms, and high continental background, Geophys. Res. Lett., 31, L22108, doi:10.1029/2004GL021596, 2004.

Wehner, B., Siebert, H., Stratmann, F., Tuch, T., Wiedensohler, A., Petäjä, T., Dal Maso, M., and Kulmala, M.: Horizontal homogeneity and vertical extent of new particle formation events, Tellus B, 59, 362-371, 2007.

Wongphatarakul, V., Friendlander, S. K., and Pinto, J. P.: A Comparative Study of $\mathrm{PM}_{2.5}$ Ambient Aerosol Chemical Databases, Environ. Sci. Technol., 32, 3926-3934, 1998.

Zhang, K. M., Wexler, A. S., Zhu, Y. F., Hinds, W. C., and Sioutas, C.: Evolution of particle number distribution near roadways, Part II: the "Road-to-Ambient" process, Atmos. Environ., 38, 6655-6665, 2004.

Zhu, Y., Hinds, W. C., Kim, S., Shen, S., and Sioutas, C.: Study of ultra fine particles near a major highway with heavy-duty diesel traffic, Atmos. Environ., 36, 4323-4335, 2002a.

Zhu, Y., Hinds, W. C., Kim, S., and Sioutas, C.: Concentration and size distribution of ultrafine particles near a major highway, J. Air Waste Manage., 52, 1032-1042, 2002b. 